\title{
Pharmacognostic Evaluation of Ten Species of Medicinal Importance of Cecropia: Current Knowledge and Therapeutic Perspectives ${ }^{\#}$
}

\author{
Authors \\ Affiliations \\ 1 Centre of Innovation and Technology Transfer, Institute \\ of Scientific Research and High Technology Services \\ (INDICASAT-AIP), Republic of Panama \\ 2 Herbario PMA, University of Panama, Republic of Panama \\ 3 Center for Pharmacognostic Research on Panamanian \\ Flora (CIFLORPAN), College of Pharmacy, University of \\ Panama, Republic of Panama
}

Andrés Rivera-Mondragón ${ }^{1}$, Orlando O. Ortíz ${ }^{2}$, Mahabir P. Gupta ${ }^{3 *}$, Catherina Caballero-George ${ }^{1(\mathbb{D})}$

Key words

Urticaceae, Cecropia, diabetes, hypertension, flavonoids

C-glycosides, ethnobotany

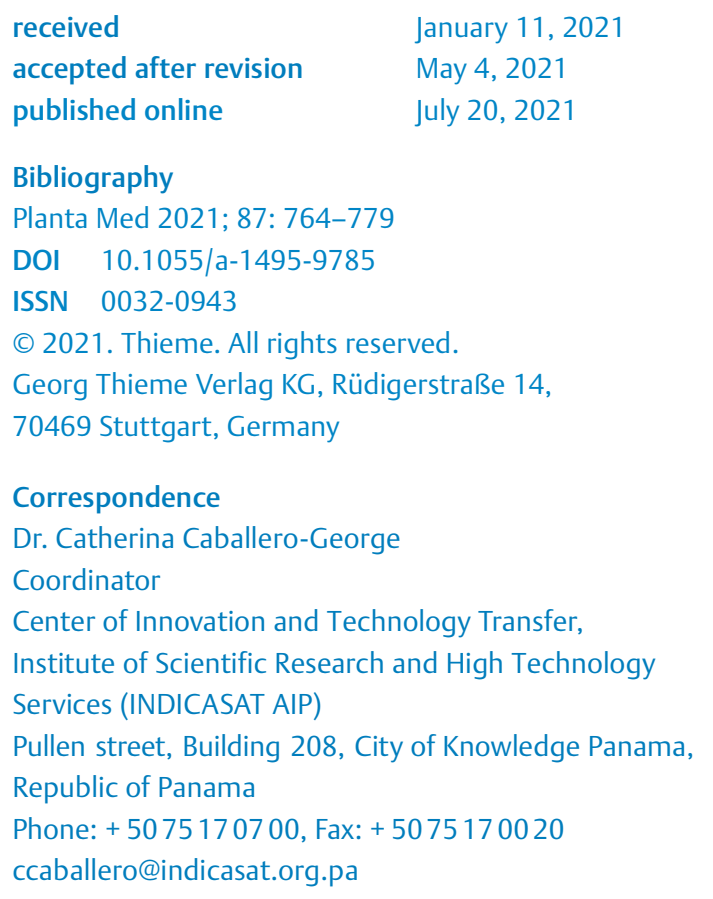

$\bigoplus \begin{aligned} & \text { Supplementary material is available under } \\ & \text { https://doi.org/10.1055/a-1495-9785 }\end{aligned}$

\begin{abstract}
This work covers a systematic review of literature about the genus Cecropia from 1978 to 2020, emphasizing the analysis of 10 of the most relevant species and their associated biological activities. Cecropia is a neotropical genus, which comprises about 61 native species in the American continent where it is known to be part of the traditional medicine of numerous countries. Secondary metabolites described for this genus showed an elevated structural and functional diversity, where polyphenols have been the most abundant. Based on this diversity, Cecropia phytochemicals represent an important source of potential therapeutic agents yet to be exploited. This review also highlights the effectiveness of combining chemometrics and ultra-performance liquid chromatography-tandem mass spectrometry as a novel approach to successfully single out Cecropia species phytochemicals. While the medicinal use of Cecropia species is officially recognized in National Pharmacopoeias and Formularies of several Latin American countries, it is important to recognize that these phytomedicines are complex mixtures requiring a thorough understanding of their chemical composition and their correlation with biological activities to guarantee their quality, safety, and efficacy.
\end{abstract}

\section{Introduction}

The genus Cecropia Loefl. (Urticaceae), with 61 described species, represents the largest genus of Cecropieae [1]. Also, it is notable for being one of the most morphologically and ecologically diverse

\# Dedicated to Professor Arnold Vlietinck on the occasion of his 80th birthday. genus in the tribe [1]. These generally fast-growing trees are widespread and abundant. They can be found across the tropical and subtropical rainforests from Mexico to South America at elevations below $2600 \mathrm{~m}$ [2]. Cecropia trees are known vernacularly as “guarumo”, “guarumbo", “yarumo”, “embaúba”, "ambay”, “trum- 
pet tree" and "torém" [3-7]. Plants within this genus are fastgrowing trees, primary colonizers of deforested areas in the tropics [8], and invasive species in non-native regions [9]. In addition, most species within the genus Cecropia are ant-plants or myrmecophytes [10]. They may live in a symbiotic relationship with a colony of symbiotic ants, especially ants of the genus Azteca [11]. They possess specialized structures for offering shelter and food to ants in exchange for protection against natural enemies [12,13].

In several Latin American countries, many species of Cecropia have been widely used in traditional medicine as a diuretic, cardiotonic, antioxidant, antitussive, and expectorant, and for the treatment of cough, asthma, hypertension, diabetes, inflammation, anxiety, and depression [4, 14-19]. There are also claims of the efficacy of plant-derived material from C. glaziovii Snethl. in wound healing, as an analgesic, and for antimicrobial activities [20].

This work covers a systematic review of the genus Cecropia obtained from classic books about traditional medicine, theses, and scientific databases including Pubmed, SciFinder, Scopus, and the Web of Science covering dates from 1978 to 2020.

Special interest has been given to 10 species of Cecropia: C. glaziovii, C. hispidissima Cuatrec., C. hololeuca, C. insignis Liebm, C. obtusa Trécul, C. obtusifolia, C. pachystachya, C. palmata Willd., C. peltata L., and C. telenitida Cuatrec., due to their medicinal importance supported by a large number of phytochemical and pharmacological data, which may promote their use as herbal drugs.

- Table 1 summarizes the ethnomedical information of 14 of the most common species within this genus, which are of both human and veterinary medicinal importance. The most frequently claimed medicinal uses were the treatment of cardiovascular diseases and diabetes, followed by the treatment of respiratory conditions. The most popularly used plant parts were the leaves, while the least used were roots and fruits. Generally, the preparation of these plant extracts mainly used water and, in some cases, alcohol.

Interestingly, C. glasiovii, C. hololeuca Miq., C. obtusefolia Bertol., and C. pachystachya Trécul. have already been recognized by local pharmacies and Ministries of Health as useful options to develop herbal products to benefit public health [4, 21-24].

\section{Classification, Taxonomy and Geographical Distribution of the Genus Cecropia}

Historically, the taxonomic classification of Cecropia was a subject of debate $[11,25]$ due to its inclusion in the Moraceae, Urticaceae, and Cecropiaceae families [25-29]. Recently, molecular phylogenetic studies $[10,11,30-36]$ positioned this genus in the tribe Cecropieae Dumort. of the Urticaceae family [9]. Cecropieae represents a monophyletic group [10] that includes dioecious trees, shrubs, and hemiepiphytes with spiral phyllotaxis, amplexicaul stipules, a reduced system of clear latex-bearing canals, aerial or stilt roots, terminal inflorescences, and staminate flowers with straight filaments [11]. Currently, this tribe comprises 5 monophyletic genera, Cecropia, Coussapoa Aubl., and Pourouma Aubl. from Neotropics, and Musanga C. Sm. ex R. Br. and Myrianthus P. Beauv. from Afrotropics [10,11].

In general terms, trees of the genus Cecropia are distinguished mainly by spathes completely enclosing the flower-bearing parts of the inflorescences, usually hollow stems, peltate blades with patches of dense indumentum (trichilia) producing Müllerian bodies at the base of the petiole, and anthers becoming detached at anthesis [1,37]. From a taxonomic point of view, this genus is relatively well studied. The most comprehensive taxonomic treatment to date corresponds to the monograph published by Berg and Franco-Rosselli [1], which also includes information on the morphological, anatomical, ecological, and geographical aspects of the genus. Table S1 (Supporting Information) shows the key morphological characteristics of the Cecropia species considered in this review.

One of the main taxonomical issues for this genus that has yet to be clarified is its infrageneric classification. The first attempt to establish an infrageneric classification of this genus was made by Snethlage [38], where 42 species were included in 2 sections, Tomentosae and Atomentosae, based on morphological differences in indumentum on perianths of staminate flowers, the length of filaments, and the length of spikes of staminate and pistillate inflorescences. According to Berg and Franco-Rosselli [1], this classification cannot be applied to all known species (probably because it was made with few specimens); therefore, it cannot be used satisfactorily. However, the authors were unable to establish a new or amended infrageneric classification in Cecropia, since insufficient knowledge on morphological differentiation was available. Despite this limitation, Berg and Franco-Rosselli recognized 2 large groups of species: $C$. peltata-group characterized by the presence of peltate stigmas, and the $C$. telenitida-group with the upper leaf surface covered with relatively dense arachnoid indumentum or glabrous, petioles usually lacking a trichilia, and the outer surface of the stipules and spathes are either glabrous or villous with long, nearly soft, whitish hairs. Recent molecular work showed C. sciadophylla Mart. (non-myrmecophytic species) as sister to the remaining studied taxa, followed by $C$. hololeuca, also, a polytomy that includes C. hispidissima Cuatrec. and C. litoralis Snethl. as well as all remaining species embedded in the Cecropia clade I (most species with Azteca mutualism) and Cecropia clade II (a group of mostly non-myrmecophytes) [10].

Another taxonomic problem pending to be resolved is the delimitation of Cecropia species that have a wide geographical distribution and high morphological variations, some of which form a complex of species, such as C. angustifolia Trécul, C. membranacea Trécul, C. obtusifolia Bertol., C. peltata L., C. pachystachya Trécul, C. latiloba Miq., C. sciadophylla, and many cryptic members of the Cecropia telenitida-group with restricted distribution [1]. A species complex occurs when there is a high morphological variation within a taxon, but there is not sufficient evidence to delimit the individual species, so all potential entities can be labeled morphotype or subspecies $[39,40]$. Recently, notable morphological and chemical differences were found in the 2 morphotypes described in C. obtusifolia, suggesting that these 2 groups may deserve a different taxonomic recognition [41]. Moreover, Santos et al. [42], through morphological and molecular data, showed major differences between $C$. pachystachya synonymized morphotypes, which raises the need for a taxonomic and nomenclatural revision of the C. pachystachya complex and subsequent reestablishment of at least 4 synonymized taxa (i.e., C. adenopus Mart. ex Miq., C. digitata Klotzsch, C. lyratiloba Miq., and C. catarinensis Cuatrec). 
- Table 1 Ethnomedical uses of Cecropia species.

\begin{tabular}{|c|c|c|c|c|c|}
\hline Species name & Common name & Plant part used & Use & Country & Reference \\
\hline $\begin{array}{l}\text { C. ficifolia Warb. } \\
\text { ex Snethl. }\end{array}$ & $\begin{array}{l}\text { Bocono/Tiopi; } \\
\text { Ambaibo }\end{array}$ & Bark & VET: vomit, scabies & Bolivia & [127] \\
\hline C. glaziovii & Embauba-vermelha & Leaves & $\begin{array}{l}\text { Heart, inflammatory and respiratory } \\
\text { conditions, diabetes, hypertension, cough, } \\
\text { and bronchitis }\end{array}$ & Brazil & {$[20,86,96]$} \\
\hline C. hispidissima & Bocino & n.s. & Skin diseases & Ecuador & {$[128]$} \\
\hline \multirow[t]{2}{*}{ C. hololeuca } & \multirow{2}{*}{$\begin{array}{l}\text { Emabaúba, Imbaúba, } \\
\text { Embaúba branca, } \\
\text { Embaúba prateada, } \\
\text { Trumpet tree, silver } \\
\text { embauva, black } \\
\text { embauva, white } \\
\text { embauva }\end{array}$} & $\begin{array}{l}\text { Leaves, fruits, } \\
\text { and sprouts }\end{array}$ & $\begin{array}{l}\text { Diuretic, diabetes, hypertension, sedative, } \\
\text { refreshing, inflammation, thoracic, healing, } \\
\text { expectorant, asthma, cough, suppressant, } \\
\text { resolutive, antithermal, adjuvant in malaria, } \\
\text { cancerous tumors }\end{array}$ & Brazil & {$[6,90,129,130]$} \\
\hline & & $\begin{array}{l}\text { Roots and/or } \\
\text { leaves }\end{array}$ & $\begin{array}{l}\text { Diabetes, diuretic (oral administration), } \\
\text { furunculosis (external use) }\end{array}$ & Brazil & {$[130]$} \\
\hline C. insignis & $\begin{array}{l}\text { Guarumo, chancarro, } \\
\text { jaruba, yagruma, } \\
\text { trumpet tree }\end{array}$ & Leaves & $\begin{array}{l}\text { Diuretic, hypertension, asthma, bronchitis, } \\
\text { and inflammation }\end{array}$ & Mexico & {$[131,132]$} \\
\hline $\begin{array}{l}\text { C. mutisiana } \\
\text { Mildbr. }\end{array}$ & $\begin{array}{l}\text { Agrumo, calentano, } \\
\text { guarumo, orumo, } \\
\text { yarumo }\end{array}$ & $\begin{array}{l}\text { Roots, leaves, } \\
\text { and bark }\end{array}$ & $\begin{array}{l}\text { Mild respiratory diseases, cough, asthma, } \\
\text { liver diseases, diabetes, an anti-inflammatory, } \\
\text { infections, scar formation, sunburns, chorea, } \\
\text { cardiac toner, heart hypertrophy, diuretic, } \\
\text { hypertension }\end{array}$ & Colombia & {$[133]$} \\
\hline \multirow[t]{2}{*}{ C. obtusa } & Imbaúba; Embaúba & Leaves & Diabetes, leishmaniasis & Brazil & [130] \\
\hline & Cetico blanco & Bark & Kidney, prostate problems & Peru & {$[134]$} \\
\hline \multirow[t]{5}{*}{ C. obtusifolia } & \multirow[t]{2}{*}{$\begin{array}{l}\text { Guarumbo, Chancar- } \\
\text { ro, Hormiguillo, } \\
\text { Chiflon and Koochl'e }\end{array}$} & Leaves & $\begin{array}{l}\text { Asthma, cough, bronchitis, fever, hepatic and } \\
\text { kidney diseases, rheumatism, inflammation, } \\
\text { obesity, heart disease, hypertension, diuretic, } \\
\text { nervousness, bradycardia, dropsy, diabetes } \\
\text { type 2, wounds, ant and scorpion stings }\end{array}$ & Mexico & $\begin{array}{l}{[23,59,80,113,} \\
135]\end{array}$ \\
\hline & & $\begin{array}{l}\text { Leaves, stem, } \\
\text { bark, and root }\end{array}$ & Diabetes type 2 & Mexico & {$[23,79,81,135]$} \\
\hline & Guarumo & Leaves and stems & Cardiovascular diseases & Panama & {$[14]$} \\
\hline & $\begin{array}{l}\text { Grayumbo, Trompeto, } \\
\text { Guarumo, Yagrumo, } \\
\text { Guarumbo, Hormi- } \\
\text { guillo and Chancarro }\end{array}$ & Leaves & Sedative, arthritis and rheumatism & El Salvador & {$[113]$} \\
\hline & Guarumbo & Sap & Warts & Mexico & {$[136]$} \\
\hline \multirow[t]{4}{*}{ C. pachystachya } & \multirow[t]{2}{*}{$\begin{array}{l}\text { Embaúba-prateada, } \\
\text { Embaúba, Ambay }\end{array}$} & Leaves, bark & $\begin{array}{l}\text { Antitussive, expectorant, asthma, diuretic and } \\
\text { hypoglycemic agent, inflammation, wound } \\
\text { healing, hypertension, cardiac diseases, and as } \\
\text { antipyretic for the treatment of fever in malaria }\end{array}$ & Brazil & {$[15,90,107]$} \\
\hline & & Powder fruit & Bronchitis & Brazil & {$[137]$} \\
\hline & Embauba, vermelha & Leaves & Skin irritation and verminosis & Brazil & {$[138]$} \\
\hline & Embauba & Leaves & $\begin{array}{l}\text { Hypertension, leukemia, pneumonia, } \\
\text { kidney disease, and cough }\end{array}$ & Brazil & {$[139]$} \\
\hline \multirow[t]{3}{*}{ C. palmata } & Torém, imbaúba & Leaves & Stimulant, tonic, and diuretic & Brazil & {$[130]$} \\
\hline & \multirow[t]{2}{*}{ embaúba-vermelha } & n.s. & $\begin{array}{l}\text { Rheumatism, inflammation, antioxidant, } \\
\text { antitumor, act in the central nervous system, } \\
\text { anxiolytic and antidepressant, asthma, hyper- } \\
\text { tension, diabetes type } 2\end{array}$ & Brazil & {$[45]$} \\
\hline & & Leaf/bark/stem & $\begin{array}{l}\text { Coronary heart disease, rheumatism, and } \\
\text { tranquilizer }\end{array}$ & Brazil & {$[140]$} \\
\hline
\end{tabular}


- Table 1 Continued

\begin{tabular}{|c|c|c|c|c|c|}
\hline Species name & Common name & Plant part used & Use & Country & Reference \\
\hline \multirow[t]{6}{*}{ C. peltata } & \multirow[t]{4}{*}{ Bois canôt } & Leaves & $\begin{array}{l}\text { Hypertension, fever, common cold and cough, } \\
\text { diabetes, rheumatism, } \\
\text { VET: skin conditions, anhydrosis, kidney } \\
\text { problem, respiratory conditions in horses }\end{array}$ & $\begin{array}{l}\text { Trinidad } \\
\text { and Tobago, } \\
\text { and British } \\
\text { Columbia }\end{array}$ & {$[141-144]$} \\
\hline & & Roots & VET: snakebite & Trinidad & [143] \\
\hline & & $\begin{array}{l}\text { Ridges from } \\
\text { inside stem }\end{array}$ & Carminative & $\begin{array}{l}\text { Trinidad and } \\
\text { Tobago }\end{array}$ & [141] \\
\hline & & Leaves & $\begin{array}{l}\text { Aches, abscesses, coughs, pains, fever, } \\
\text { pertussis, pharyngitis, gingivitis, bronchitis, } \\
\text { skin lesions, antiparasitic agent, digestive } \\
\text { problems, antibilious, cardiotonic, diuretic } \\
\text { agent, against blennorrhea and warts }\end{array}$ & $\begin{array}{l}\text { Nicaragua, } \\
\text { Jamaica, } \\
\text { Guatemala, } \\
\text { Colombia }\end{array}$ & {$[97,109,145-148]$} \\
\hline & Imbaúba, simbaúba & & Heart diseases and diabetes. & Brazil & [130] \\
\hline & Guarumo/Yarumo & & $\begin{array}{l}\text { Asthma, bronchitis, lung diseases, blood and } \\
\text { circulatory system, heart diseases, gallbladder, } \\
\text { sunstroke, diuretic, cardiovascular, metabolic, } \\
\text { and respiratory disorders, for their wound- } \\
\text { healing and diuretic, diabetes mellitus, heart } \\
\text { diseases and hypertension, sedative and anti- } \\
\text { microbial agent, albuminuria, kidney infec- } \\
\text { tions, heart conditions and nervous diseases, } \\
\text { and to promote good kidney function }\end{array}$ & Colombia & $\begin{array}{l}{[5,59,70,77,80,} \\
109,130,141,149, \\
150]\end{array}$ \\
\hline $\begin{array}{l}\text { C. schrebiana } \\
\text { Miq. }\end{array}$ & Yagruma & Leaves & Asthma, anticatarrhal, cardiotonic & Cuba & {$[151,152]$} \\
\hline C. sciadophylla & Bocobí; hierba de loro & & VET: Respiratory system (cold and flu) & Bolivia & [127] \\
\hline C. telenitida & $\begin{array}{l}\text { Guarumo; guarumbo; } \\
\text { yarumo plateado; } \\
\text { yarumo blanco }\end{array}$ & & Inflammation & Colombia & {$[7,153]$} \\
\hline
\end{tabular}

\section{Phytochemistry}

\section{Extraction and methods of analysis}

Most studies on Cecropia have mainly focused on the polar constituents found in its leaves. Water and hydroalcoholic mixtures $\left(\mathrm{H}_{2} \mathrm{O}\right.$ : $\mathrm{EtOH}$ or $\left.\mathrm{H}_{2} \mathrm{O}: \mathrm{MeOH}\right)$, commonly chosen as extraction solvents, are described as the most appropriate systems for polyphenol extraction. Nevertheless, other solvents such as butanol and ethylacetate (EtOAc) have been also utilized.

Among the extraction methods, the most frequently used were maceration, infusion, decoction, Soxhlet extraction, and ultrasound-assisted extraction. Optimal extraction methods have been evaluated by only a few studies $[43,44]$, where the best extraction parameters were estimated by statistical approaches to reduce the number of experiments and to investigate the effects of various factors, such as temperature, extraction time, and solvent concentration. According to these investigations, extracts with $70 \%$ and $80 \%$ ethanol (EtOH) presented a higher chlorogenic acid, total flavonoid, and flavonolignans content, while extracts with $20 \%$ EtOH showed a higher caffeic acid concentration.

High-performance liquid chromatography coupled to a diode array detector (HPLC-DAD) was the most common analytical technique used to identify and quantify the secondary metabolites in these extracts by a targeted approach (Table 2S, Supporting Information). The identity of polyphenols is usually confirmed by comparison with both the retention time and UV spectrum of authentic standards.

Interestingly, liquid chromatography coupled with mass spectrometry (such as UPLC-MS/MS) has been established as a powerful technique for rapid analysis of nonvolatile compounds found in Cecropia, and electrospray ionization in positive and negative ion mode has been identified as the most useful ionization technique. Additionally, identification of compounds was based on different levels of confirmation: structure confirmed by comparison with authentic standards, possible structure by library spectrum match, and proposed candidates based on $\mathrm{MS}^{2}$ experimental data.

Full identification of the chemical structure of novel compounds found in Cecropia was performed by NMR spectroscopy: yarumic acid ( $C$. telenitida), isoyarumic acid (C. telenitida), entmururin A (C. obtusifolia), and ent-mururin B (C. obtusifolia).

Extensive research has been focused on the phenolic compounds of polar extracts, while fewer phytochemical studies have included nonpolar constituents of Cecropia leaves. Schmidt et al. [45] showed, by HPLC-DAD (210 nm) and UHPLC-MS/MS analysis, that EtOAc was more efficient extracting triterpenes from $C$. obtu- 


\section{Cinnamic acid derivatives}<smiles>O=C(/C=C/c1ccc(O)c(O)c1)O[C@H]1C[C@@](O)(C(=O)O)C(O)C(O)C1O</smiles>

Chlorogenic acid

Benzoic acid derivatives<smiles>O=C(O)c1ccc(O)c(O)c1</smiles>

Protocatehuic acid<smiles>O=C(O)/C=C/c1ccc(O)c(O)c1</smiles>

Caffeic acid<smiles>COc1cc(C(=O)O)ccc1O</smiles>

Vanillic acid<smiles>COc1cc(/C=C/C(=O)O[C@H]2C[C@](O)(C(=O)O)C[C@H](O)C2O)ccc1O</smiles>

5-O-Feruloylquinic acid

Galloyl rhamnoside

- Fig. 1 Chemical structures of main phenolic acids reported for plants of the genus Cecropia.

sa and C. palmata than chloroform. Additionally, Guerrero et al. [46] used GC-MS analyses to show the presence of phenolic acids (vanillic acid), tetracyclic triterpenoids (stigmast-4-en-3-one, 4cholestene-3,24-dione, 4,22-cholestadien-3-one), fatty acids (palmitic acid, stearic acid), and other nonpolar compounds such as 4-vinyl-2-methoxy-phenol, 2-methylbenzaldehyde, 2,3-dihydrobenzofuran, and 3'-methoxyacetophenone, in the dichloromethane extract of $C$. obtusifolia leaves.

\section{Chemical Constituents}

Available literature describes the phytochemistry of the genus $\mathrm{Ce}$ cropia consisting of almost 100 identified compounds, which include phenolic compounds, particularly phenolic acids, flavonoids, condensed tannins, triterpenoids [7,47,48], flavonolignans, and iridoids [49]. Names and source of these constituents are listed in Table $2 \mathrm{~S}$ (Supporting Information) and their structures in > Figs. 1-3.

\section{Phenolic acids}

Phenolic constituents dominate the chemistry of Cecropia, being one of the most studied constituents in this genus. Several phytochemical investigations have revealed the presence of cinnamic acid derivatives (chlorogenic acid, caffeic acid, sinapic acid hexoside, and 5-O-feruloylquinic acid) and benzoic acid derivatives (protocatehuic acid, vanillic acid, and galloyl acid derivatives) ( $\bullet$ Fig. 1).

Chlorogenic acid, the ester of caffeic acid with quinic acid, is the main phenolic acid found in all Cecropia species, reaching a concentration of up to $28 \mathrm{mg} / \mathrm{g}$ of aqueous leaf extract in C. pachystachya (Table 2S, Supporting Information). Due to its good chemical stability, pharmacological relevance, and relatively high concentration, chlorogenic acid has been selected as an appropriate chemical marker for the chemical standardization and quality evaluation of Cecropia products [50].

\section{Flavonoids}

Flavonoids constitute another important group of compounds observed in Cecropia species (Table 2S, Supporting Information and - Fig. 2), which are found in relatively high concentrations [44, $49,51,52]$. Many studies have associated flavonoids with the biological and pharmacological effects described for Cecropia [4]. Among the broad variety of flavonoids detected, the majority belonged to the flavone or flavonol classes, with luteolin, apigenin, or quercetin being the main aglycones.

Within this class, flavones derived from the aglycones luteolin and apigenin were the main subclass of flavonoids present in Cecropia, predominantly in the form of monoglycosides and diglycosides with different sugar units, such as hexoses, pentoses, and deoxyhexoses. Among flavone glycosides, $C$-linked monoglycosyl flavones, such as isoorientin, orientin, isovitexin, and vitexin were the most abundant, with isoorientin being the main constituent in C. glaziovii, C. hololeuca, C. insignis, C. obtusifolia, C. pachystachya, and $C$. peltata $[16,41,44,49,52-54]$. The occurrence of di- $C, O$ glycoside flavones was also described $[44,49,54]$.

It is noteworthy that the diversity of flavones glycosides observed in Cecropia was strictly due to differences in sugar units and types of glycosidic bonds, while aglycones remained similar for almost all species [49].

Other minor flavonoids found in C. hololeuca, C. insignis, C. obtusifolia, C. pachystachya, and C. peltata included methylated derivatives, such as scoparin (diosmetin-8-C-hexoside) and scoparin2"-O-rhamnoside [49,54].

Regarding the effect of seasonal variation on flavonoid content, Rivera-Mondragón et al. [44] showed that there was no clear correlation of those variables in C. insignis, C. hispidissima C. obtusifolia, and C. peltata, collected in Panama. Similar findings were described by Costa et al. [55], where no correlation was found between pluviosity and the production of C-glycosylflavonoids in C. glaziovii collected in Brazil. In contrast, Luengas-Caicedo et al. 


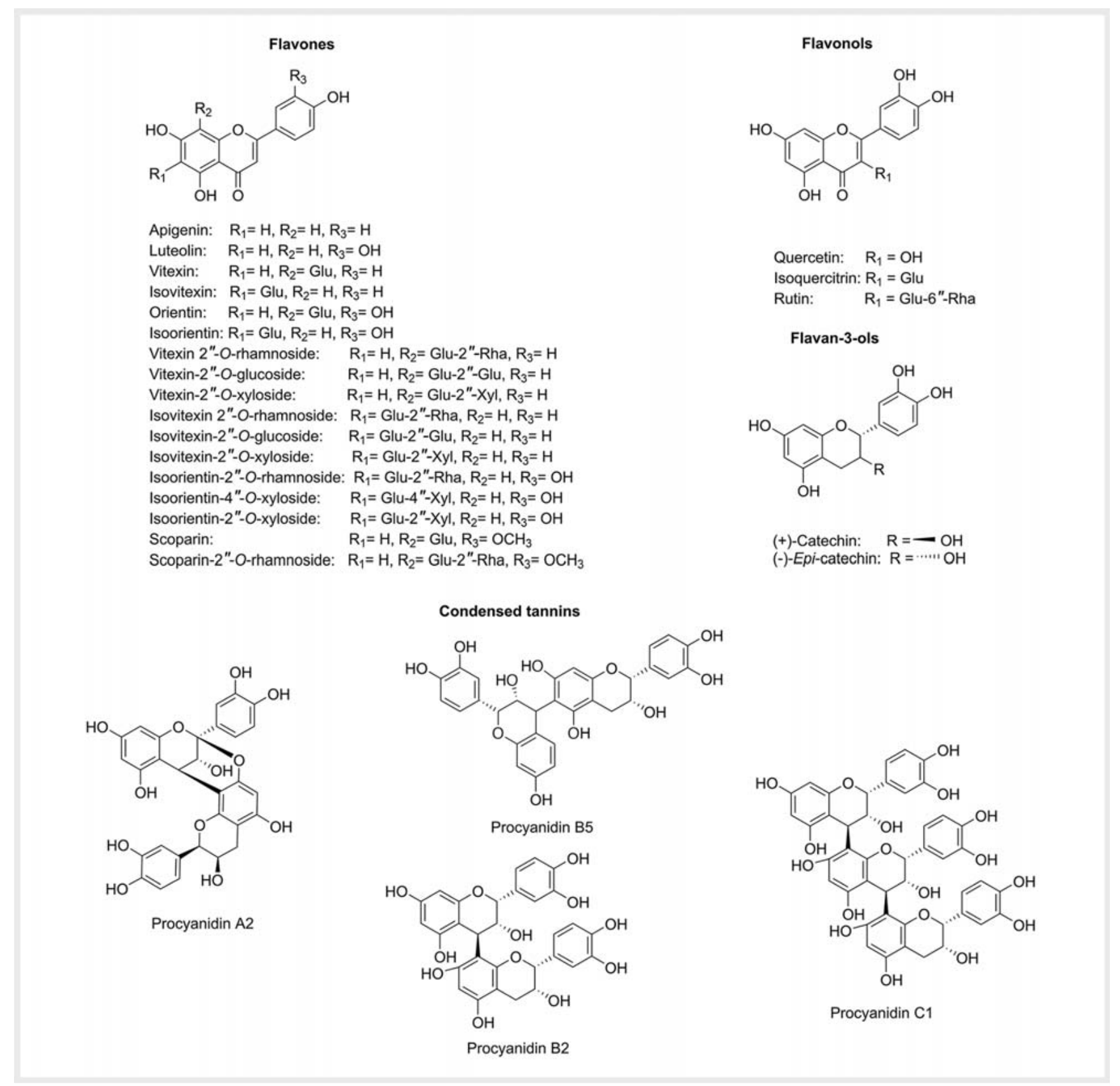

- Fig. 2 Chemical structures of main flavonoids reported for plants of the genus Cecropia.

[3] found a higher flavonoid content in C. glaziovii leaf extracts collected in Brazil during the dry season compared to those collected during the rainy period.

The presence of flavonols in the genus Cecropia was remarkable. Within this sub-class of flavonoids, quercetin, rutin, and isoquercitrin were predominant in some Cecropia species [15,44, 49, 54, 56-58] (Table 2S, Supporting Information). Other flavonol Oglycosides, like quercetin 3-O-hexoside, isorhamnetin-3-O-hexoside, and isorhamnetin-3-O-rutinoside, have also been characterized in C. hololeuca [49] (Table 35, Supporting Information), while flavan-3-ols such as (+)-catechin and (-)-epicatechin have been found in the aqueous, methanolic, or ethanolic extracts of C. pachystachya, C. glazoivii, and C. hololeuca leaves [15, 20, 21, 49, 56].

\section{Condensed tannins}

All condensed tannins found in the Cecropia species belonged to the procyanidin family, consisting of oligomers or polymers of catechin, epicatechin, and/or gallocatechin. Procyanidin A2, B2, B5, and C1 were reported in both free and glycosidic forms (Table 2S, Supporting Information and $>$ Fig. 2). These compounds have been mainly identified in species from South America: C. pachystachya, C. glaziovii, and C. hololeuca. Catechin and epicatechin, the 


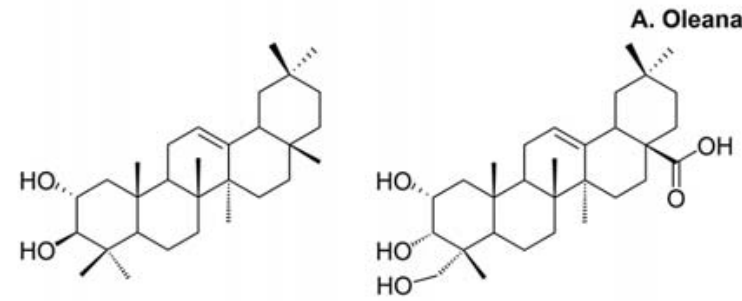

$\beta$-Amyrin

Isoarjulonic acid<smiles>CC1(C)CCC2(C(=O)O)CCC34C(=CCC3C23CCC2C(C)(C)C(O)CCC23C)CC14</smiles>

Oleanolic acid<smiles>CC1(C)CCC2(C(=O)O)CCC3(C)C4=CCC5CCC1C2CCC3C4(C)CCC1C5CC(O)C(O)C1(C)C</smiles>

Maslinic acid<smiles>COC(=O)[C@]1(C)CC[C@@]2(C(=O)O)CCC3(C)C(=CCC4C5CCC6C(C)(C)C(O)CCC6(C)C5CCC43C)C2C1</smiles>

Serjanic acid<smiles>COC(=O)[C@]1(C)CC[C@]2(C(=O)O)CCC3(C)C(=CCC4C5(C)CCC(OC(C)=O)C(C)(C)C5CCC43C)C2C1</smiles>

Spergulagenic acid $A$<smiles>CC1(C)CCC2(C(=O)OC3OC(CO)C(O)C(O)C3O)CCC3(C)C4=CCC5C(C)(CCC6C(C)(CO)C(O)C(O)CC65C)C4C3C(O)C2C1</smiles>

Buergericic acid 28-O-glucoside

B. Ursane-type triterpene
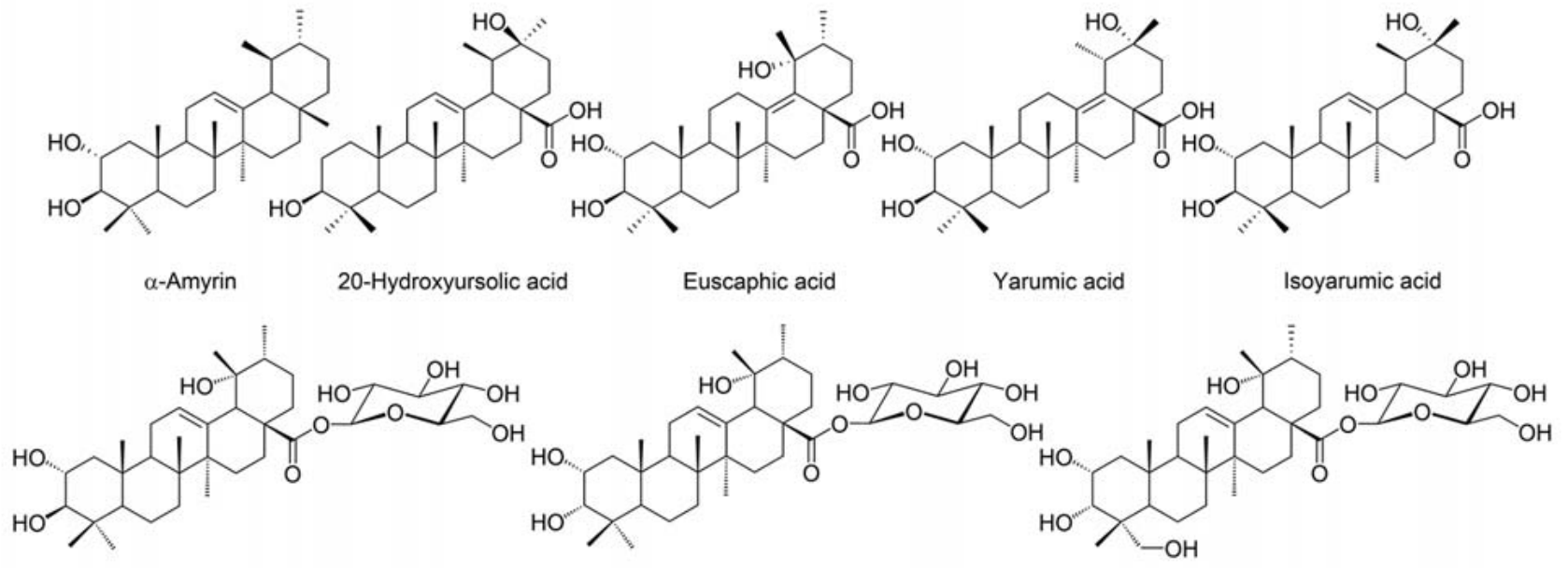

Tormentoside

Kaji-ichigoside F1

Niga-ichigoside F2

\section{Lupane-type triterpene}

\section{Steroids}<smiles>C=C(C)[C@H]1CCC2(C)CCC3(C)C(CCC4C5(C)CCC(O)C(C)(C)C5CCC43C)C12</smiles>

Lupeol<smiles>CCC(CCC(C)C1CCC2C3CC=C4CC(O)CCC4(C)C3CC[C@]12C)C(C)C</smiles>

$\beta$-Sitosterol<smiles>CCC(/C=C/C(C)C1CCC2C3CC=C4CC(O)CCC4(C)C3CCC12C)C(C)C</smiles>

Stigmasterol<smiles>CCC(CCC(C)C1CCC2C3CCC4=CC(=O)CCC4(C)C3CCC12C)C(C)C</smiles>

Stigmast-4-en-3-one

- Fig. 3 Chemical structures of main terpenoids reported for plants of the genus Cecropia.

precursor of procyanidins, were also frequently detected in different extracts of this plant.

\section{Pentacyclic triterpenoids and steroids}

Interestingly, Cecropia plants are also a rich source of triterpenes and steroids (Table 2S, Supporting Information and • Fig. 3).
The main triterpenoid skeletons found in Cecropia belonged to the pentacyclic oleanane-, ursane- and lupane groups. Several pentacyclic terpenoids found in roots were aglycones. Yarumic acid, isoyarumic acid, serjanic acid, spergulagenic acid A, 20-hydroxy-ursolic acid, and goreishic acid I were obtained from the dichloromethane and EtOAc extracts of the root of C. telenitida 
$[7,47,48]$. Moreover, hydroalcoholic leaf extracts were rich in saponins (triterpenoid glycosides), having glucose moieties located predominantly at the C-28 position. Rivera-Mondragon et al. reported the presence of niga-ichigoside F2, kaji-ichigoside $\mathrm{F} 1$, tormentoside, and buergericic acid 28-O-glucoside in C. obtusifolia, C. peltata, C. insignis, and C. hispidissima [54], while Schmidt et al. [45] identified lupeol, $\alpha$-amyrin, $\beta$-amyrin, oleanolic acid, and maslinic acid in C. obtusa and C. palmata.

Steroids such as stigmasterol, sitosterol, stigmast-4-en-3-one, 4-cholesten-3,24-dione, and 4,22-cholestadien-3-one have also been described $[45,46,59,60]$.

Table 2S (Supporting Information) shows the most important triterpenoids and steroids identified in Cecropia. No essential oils have been described for this genus in the literature consulted for the present review.

\section{Other constituents}

While most phytochemical studies focused on identifying and isolating flavonoids, other components that have gained less attention are worth mentioning in this review. For instance, the iridoids geniposide 1 and 2 were found in the leaves of $C$. pachystachya and C. hololeuca [49] and the flavonolignans ent-mururin A and entvaccinin $A$ in the leaves of $C$. obtusifolia [61]; the coumarins 4-ethyl-5-(n-3valeroil)-6-hexahy-drocoumarin, scopoletin [4, 59], some organic acids, anthraquinones, and 1 alkaloid were also found in Cecropia species (Table 4S, Supporting Information) [59, 62, 63].

\section{Metabolomics Approach}

Recently, metabolomic approaches such as LC-HRMS, mainly through untargeted data-dependent MS/MS methods, have provided new standpoints to help the chemical profiling and fingerprinting of several medicinal plants. Untargeted metabolomics in combination with chemometrics analysis is a powerful approach for detecting as many metabolites as possible and provides an appropriate platform for comparing and revealing important differences among plant species.

Significant efforts have been carried out by applying this approach to Cecropia species. For instance, tentative identification of 37 compounds in C. pachystachya and C. hololeuca, including flavonoids, phenolic acids, flavan-3-ols, condensed tannins (procyanidins), and iridoids, was carried out through UV analysis and MS/MS [49]. This study showed that C. pachystachya produced a higher diversity of flavones than $C$. hololeuca and that orientin and isoorientin were the major flavones in both plant species. Similarly, high-performance liquid chromatography-diode array detection-quadrupole time of flight-tandem high-resolution mass spectrometry (HPLC-DAD-QTOF) in positive and negative ionization mode identified 47 chemical constituents in the leaves of 6 Cecropia species $[41,54]$. These compounds included 2 phenolic acids, 33 flavonoids, 3 flavonolignans, and 9 saponins, many of which were found to be unknown for these species. Chemometric analysis, such as hierarchical cluster analysis and principal component analysis, revealed that the most abundant flavonoids detected in C. angustifolia, C. insignis, C. obtusifolia, C. peltata, and C. telenitida were flavone C-glycosides. Interestingly, C. hispidissima was the most segregated species, due to its high relative con- centration of flavonol mono- and diglycosides. Additional findings showed that C. obtusifolia "burriada-type" and "obtusifolia-type" belonged to different clusters, proposing an inaccurate taxonomic classification of these species [41]. This study also showed that the chemical profile of the leaf of $C$. obtusifolia "burriada- type" was the most diverse of all studied species, while $C$. telenitida showed the lowest diversity.

\section{Pharmacological Effects}

Numerous studies highlighting the pharmacological properties of different extracts of Cecropia species are summarized vide infra in this review.

\section{Antioxidant Effect and Skin Protection}

While the antioxidant capacity of the genus Cecropia has been widely studied, its wound healing and skin protection potential have only been recently studied. More than $50 \%$ free radical scavenging capacity was observed when an aqueous extract of C. hololeuca bark [64] and a methanolic $[16,65]$ extract and hydroethanolic and ethanolic [66] extracts of $C$. pachystachya leaves were tested in different antioxidant models, such as phosphomolybdenum, 1,1-diphenyl-2-picrylhydrazine, carotene/linoleic acid bleaching, and thiobarbituric acid reactive substances (Table 5S, Supporting Information).

Additionally, both an ethanolic and a hydroethanolic extract of C. pachystachya prevented the production of advanced glycation end products (Table 5S, Supporting Information) and were able to stimulate fibroblasts proliferation in vitro, with no sign of cytotoxicity [66].

Collagenase levels and elastase activity were reduced by a hydroethanolic extract of $C$. pachystachya [66], while an ethanolic extract of the leaves of $C$. obtusa decreased collagenase and protein carbonyl levels [67]. Chlorogenic acid, the main component of C. obtuse, was also capable of increasing collagen and hyaluronic acid contents. Furthermore, $C$. obtusa extract prevented the formation of UV-induced pro-inflammatory cytokines IL- $1 \beta$ and IL- 6 in HaCaT keratinocytes [67] (Table 5S, Supporting Information), protected keratinocytes from UVA-induced damage, and absorbed UVA/UVB radiation, while showing a good radical scavenging capacity (Table 5S, Supporting Information) [68].

Gels containing $2 \%$ and $5 \%$ of an ethyl acetate extract of C. pachystachya promoted the healing process in rats, causing less neovascularization and cellularity, better tissue repair, and younger and more homogeneous tissue when compared to the control. These effects, together with the antioxidant properties shown by this extract (Table 5S, Supporting Information), propose a further evaluation of this plant as a topical treatment in the management of skin lesions [69].

In the same line, the aqueous and ethanol extracts of $C$. peltata significantly reduced injured areas in animals (Table 5S, Supporting Information) and showed clean wounds with healthy granulation tissue. In all groups treated, an increase in protein content, hydroxyproline, and hexosamine was observed, as well as a better lay-down of collagen when compared to respective controls [70]. 


\section{Hypoglycemic Effect and Anti-diabetic Potential}

Available literature showed that polar extracts of the leaves of C. glaziovii, C. obtusifilia, C. pachystachia, and C. peltata had a hypoglycemic effect in different animal models.

Thus, a standardized hydroalcoholic extract of $C$. glaziovii showed antihyperglycemic activity and improved glucose tolerance in diabetic rats [71]; aqueous and butanol extracts of $C$. obtusifolia significantly reduced blood glucose levels in normal and pancreatectomized dogs [72], diabetic rats [73], diabetic mice [74], and hyperglycemic rabbits [75, 76], and its methanol extract reduced plasma glucose in healthy mice [77] (Table 5S, Supporting Information). Interestingly, the hypoglycemia observed by the aqueous extract of $C$. obtusifolia was not accompanied by a rise in plasmatic insulin, suggesting that this effect was unrelated to beta-pancreatic cell stimuli [72]. These extracts showed similar hypoglycemic effects to $3 \mathrm{mg} / \mathrm{kg}$ glibenclamide. Isoorientin and chlorogenic acid, the main constituents of these extracts, were proposed as responsible agents of the hypoglycemic effects of both extracts $[73,78,79]$. Isoorientin reverted TNF- $\alpha$-induced insulin resistance in adipocytes, activating the insulin signaling pathway [79], and showed a strong antioxidant effect that may also contribute to the hypoglycemic effect of chlorogenic acid [59].

Moreover, a butanol extract of C. obtusifolia inhibited gluconeogenesis in diabetic rats $[75,79]$ and $\alpha$-glycosidase activity in vitro [78] and reduced glucose-6-phosphatase activity in rat liver microsomes [80] (Table 5S, Supporting Information).

Clinical studies carried out for $C$. obtusifolia aqueous extract showed a noteworthy and sustained hypoglycemic effect in type 2 diabetic patients after 32 weeks of treatment (Table 5S, Supporting Information). Glycosylated hemoglobin reduction was also seen after 6 weeks of administration of this extract (Table 5 S, Supporting Information), with no significant changes in insulin secretion, alanine aminotransferase, aspartate aminotransferase, and alkaline phosphatase levels, indicative of no hepatotoxicity [81]. In another study, this extract administered with glibenclamide produced a considerable hypoglycemic effect and was effective in reducing fasting blood glucose (Table 5S, Supporting Information) [82]. Furthermore, isoorientin decreased circulating radical scavengers in diabetic patients and reduced symptoms of associated complications [59]. Altogether, these findings promote the development of C. obtusifolia as an antidiabetic agent [83].

Similar to C. obtusifolia, a butanol and an aqueous extract of C. peltata prevented the rise of plasma glucose and inhibited gluconeogenesis [80,84] and glucose-6-phosphatase activity [80]. In addition, methanol extracts of $C$. peltata and C. pachystachya, mainly constituted by chlorogenic acid and isoorientin [84], produced hypoglycemia in diabetic rats $[65,77]$ (Table 5S, Supporting Information).

\section{Cardiovascular Effect}

Extracts of the leaves of 3 species of Cecropia, namely C. glaziovii, C. obtusifolia, and C. pachystachya, were studied for their hypoten- sive effect on both hypertensive and normotensive rodent models.

Oral administration of aqueous and butanol extracts of $C$. glaziovii, as well as intravenous administration of $C$. glaziovii (butanol) $[85,86]$ and C. obtusifolia (aqueous and ethanol), produced hypotension [87-89]. These studies suggested that the effect caused by the butanol extract of $C$. glaziovii was mediated by the reninangiotensin system [86], while hypotension induced by its aqueous extract was independent of the inhibition of the angiotensinconverting enzyme (ACE) (Table 5S, Supporting Information) [87].

Vasodilation produced by a methanol extract and a flavonoid containing a fraction of $C$. lyratiloba was endothelin dependent, possibly by stimulation of NO production. Interestingly, while the crude extract was active, its main flavonoids isoorientin and a mixture of orientin/isovitexin were inactive when individually tested [90]. Furthermore, this flavonoid-containing fraction induced cardiac depression and inhibited adrenaline-induced contractions in aortic rings (Table 5S, Supporting Information) [90, 91]. Similarly, a standardized hydroalcoholic extract of $C$. glaziovii caused ring aorta relaxation (Table 5S, Supporting Information) [71], as well as its butanol fraction. The latest fraction also blocked the peak $\mathrm{Ca}^{++}$current in chromaffin cells of a PC12 cell line [85].

The aqueous extract of $C$. pachystachya caused hypotension and tachycardia [24], possibly due to the central blockage of sympathetic nerves of vessels and central cholinergic inhibition of the heart. It was also suggested that its cardiotonic effect may be due to inhibition of the Na/K pump [92]. In addition, C. pachystachya also reduced inflammation and renal lesions associated with ACEinhibition, reduction of macrophage infiltration, angiotensin II and c-jun $\mathrm{N}$-terminal kinase expression, and arginase activity in the renal cortex of rats (Table 5S, Supporting Information) [93, 94]. Also, the aqueous extract of the leaves of $C$. peltata showed a positive inotropic effect on isolated guinea pig atria and caused injury to cardiomyocytes [95].

To understand the mechanisms by which these extracts and their constituents may interact with the cardiovascular system, additional in vitro studies were carried out and their findings summarized below.

A methanol fraction of the spitules of $C$. glaziovii almost completely inhibited ACE activity, while a similar type of extract of its leaves showed half of this effect [58]. The ethanol extract of C. hololeuca also inhibited ACE activity (Table 5S, Supporting Information). The major components within these active extracts were identified as orientin, isoorientin, $(+)$-catechin, (-)-epicatechin, and 2 (-)-epicatechin-derived oligomeric procyanidin B2, procyanidin $\mathrm{C} 1$, and chlorogenic and protocatechuic acids [58]. Interestingly, while these compounds showed little activity when tested individually, the fraction containing mainly procyanidins showed almost a complete inhibition of ACE activity at the same concentration [58].

Moreover, a radioligand-binding-based in vitro study was used to test the methanol/dichloromethane $(1: 1)$ and the ethanol extracts of the stems and leaves of $C$. obtusifolia. The results showed that both extracts inhibited angiotensin II binding to the angiotensin II type 1 receptor and BQ-123 binding to the endothelin-1 
type A receptor in more than $50 \%$ of the control (Table 5S, Supporting Information) [14].

\section{Anti-inflammatory Effect}

Different plant parts of only 4 Cecropia species have been studied for their anti-inflammatory properties.

Thus, aqueous extract of the leaves of C. glaziovii reduced proinflammatory cytokines, cell infiltrates, myeloperoxidase activity, nitrite/nitrate concentration, lactate dehydrogenase activity, and total protein levels with concomitant attenuation of all parameters associated with oxidative damage caused by carrageenin. Chlorogenic acid, isoorientin, and isovitexin were identified as the major compounds of this active extract [96].

The aqueous extract of the bark of $C$. hololeuca reduced mouse paw edema and decreased the production of nitric oxide, tumor necrosis factor-alpha (TNF- $\alpha$ ), and interleukin-1-beta (IL-1 $\beta$ ) on murine macrophages J774A.1 cells (Table 5S, Supporting Information), without signs of cytotoxicity [64].

Nonpolar extracts of the leaves of $C$. pachystachya, like hexane and dichloromethane, and 2 of its main constituents, $\beta$-sitosterol [97] and pomolic acid, reduced the inflammatory response in carrageenan-induced mouse paw edema. Moreover, pomolic acid reduced the in vivo production of IL- $1 \beta$ by hindering the viability of neutrophils through apoptosis. Trans-phytol, $\alpha$-amyrin, and ursolic acid, identified also in the dichloromethane extract, showed anti-inflammatory effects as well (Table 5S, Supporting Information) [60]. Besides, its methanolic extract showed acute and topical anti-inflammatory properties in ear edema (Table 5S, Supporting Information) [16,98] and a moderate chronic skin anti-inflammatory effect with a decrease in vasodilation, edema, cell infiltration, and epidermal hyperproliferation [16].

Lastly, in the roots of $C$. telenitida a couple of pentacyclic triterpenes, namely serjanic acid and spergulagenic acid $A$, blocked the secretion of proinflammatory cytokines (IL-1 $\beta$, IL-12p40, IL12 p70, TNF- $\alpha$ ) in a dendritic cell-based assay. Moreover, spergulagenic acid $A$ also inhibited nitric oxide production in lipopolysaccharide-stimulated dendritic cells [7].

\section{Central Nervous System Effects}

The butanol fraction of $C$. peltata, rich in flavonoids, showed anticonvulsant, anxiolytic, and sedative effects in mice at $80 \mathrm{mg} / \mathrm{kg}$. These effects were greater than ethanolic, aqueous, and hexane fractions [5, 99].

An antidepressant effect was caused by the aqueous extract of the leaves of $C$. glaziovii and its butanol fraction. The results proposed that this effect may be due to the blockade of monoamine uptake, mainly the uptake of $[3 \mathrm{H}]$-noradrenaline. Biochemical analysis of the animals treated with the flavonoids containing fraction showed a significant increase in monoamines levels in the hippocampus (Table 5S, Supporting Information) [100].

In addition to that, an antidepressant effect was also seen by oral administration of an enriched C-glycosyl flavonoid fraction and an aqueous extract obtained from leaves of $C$. pachystachya $[15,101]$. These extracts prevented both behavioral (hyperlocomotion) and pro-oxidant effects (an increase of lipid peroxidation and carbonyl protein formation, and a decrease in total thiol content) of ketamine in a rat model of mania. These effects were thought to be mediated by chlorogenic acid, orientin, isoorientin, isovitexin, and isoquercitrin present in both extracts [57]. The sedative effect produced by $C$. pachystachya aqueous extract (180-600 mg/kg) was comparable to diazepam $10 \mathrm{mg} / \mathrm{kg}$ [92].

C. pachystachia was also studied for its antinociceptive effect. A methanol extract of its leaves was effective, in a dose-dependent manner, against pain induced by acetic acid and on the second phase of the formalin test (Table 5S, Supporting Information) [98].

\section{Other Biological Effects}

Extracts of C. glaziovii, C. obtusifolia, C. pachystachya, and C. peltata have been also studied for additional biological activities, namely, antihistamine-induced bronchospasm, cytotoxicity, antimicrobial, gastric mucosal protection, and genotoxicity.

Administration of a standardized aqueous extract, as well as a procyanidin/flavonoids- enriched butanol fraction of the leaves of C. glaziovii, showed protection against histamine-induced bronchospasm in guinea pigs. Moreover, in vitro incubation of a flavonoid enriched butanol fraction decreased the maximal response of tracheal muscle to histamine without modifying the $\mathrm{EC}_{50}$, suggesting a noncompetitive inhibitory effect of $C$. glaziovii to histamine (Table 5S, Supporting Information). Bronchodilation caused by this extract appeared to be related to $\beta$-adrenergic activity since this effect was prevented by pretreatment with propranolol [102].

A methanol extract of the leaves of $C$. pachystachya significantly diminished the viability of human promyelocytic leukemia cells expressing $\mathrm{Bcl}-2$ and human immortalized line of T lymphocyte (Jurkat cells) (Table 5S, Supporting Information) in a study proposing the capacity of the extract to overcome resistance due to its ability to downregulate the anti-apoptotic oncoprotein $\mathrm{Bcl} 2$ [98]. Another study carried out on human prostate adenocarcinoma cells showed the capacity of its triterpene-enriched fraction to reduce the number of viable cells by senescence induction (Table 5S, Supporting Information) [103]. Furthermore, the triterpenes tormentic, 2- $\alpha$-acetyl tormentic, 3- $\beta$-acetyl tormentic, and euscaphic acids, obtained from the dichloromethane fraction of a methanol extract of $C$. lyratiloba roots, were cytotoxic against sensitive and multidrug-resistant leukemia cell lines (Table 5S, Supporting Information) [104-106]. These findings emphasize the potential of some species of Cecropia to be further studied as anticancer agents.

Other studies also evaluated the antiparasitic and antibiotic properties. Thus, ethanol extracts of woods, roots, and leaves, as well as a hexane extract of the roots of $C$. pachystacya, showed a reduction in the parasitemia of malaria-infected mice (Table 5S, Supporting Information) [107], while chlorogenic acid, catechin, epicatechin, isoquercitrin, and orientin (from the ethyl acetate fraction of its leaves) inhibited Leishmania (L.) amazonensis promastigotes arginase activity (Table 5S, Supporting Information) [56]. Moreover, orientin, isoorientin, vitexin, isovitexin, rutin, and chlorogenic acid obtained from this plant were described as quorum sensing (QS) inhibitors using Chromobacterium violaceum (in- 
hibition of violacein pigment) and Escherichia coli (bioluminescent inhibition) as biosensors in the agar diffusion tests (Table 5S, Supporting Information) [108]. Similarly, the ethanolic extract of C. peltata was studied for its antimicrobial effect and shown to be active against Staphylococcus aureus, Bacillus cereus, and E. coli (Table 5S, Supporting Information) [109].

Further studies about the biological effects of C. glaziovii extracts showed that the ethanol extract of its leaves reduced liver injury and was active against Herpes simplex virus type 1 (acyclovir-resistant strain) (Table 5S, Supporting Information) [110]. Another study showed that the aqueous extract of this plant and its butanol fraction reduced the total acidity of gastric secretion, the index of mucosal damage, and the number of ulcers in pylorusligated mice (Table 5S, Supporting Information) [20]. The results also showed that the butanol fraction and its main constituents isoorientin, orientin, isovitexin, catechin, epicatechin, and procyanidin B2, B3, B5, and C1 had equal potency inhibiting gastric $\mathrm{H}+, \mathrm{K}+$ ATPase enzyme activity, when tested both individually and in a complex mixture (Table 5S, Supporting Information) [20]. Feltrin et al. showed that a standardized extract of this plant was able to inhibit 2 cytochrome P450 enzymes, namely CYP3A4 and CYPD6 (Table 5S, Supporting Information), a characteristic that may modify the bioavailability and efficacy of certain drugs [62].

There are few studies available describing the acute and chronic toxicity of the genus Cecropia, as well as their effect on fetal development and genotoxicity. In this regard, a hydroalcoholic extract of $C$. glaziovii and an aqueous extract of $C$. obtusifolia showed no relevant toxicity on rats nor in their litters (Table 5S, Supporting Information) [111-113]. Moreover, C. obtusifolia leaf extract was not cytotoxic nor genotoxic in either the Drosophila wing somatic mutation or the human micronucleus assay [114]. Additional studies showed that oral administration of an aqueous extract of the leaves of $C$. pachystachya $(2 \mathrm{~g} / \mathrm{kg})$ was not genotoxic nor mutagenic in rats [115], with no sign of toxicity in mice [116]. However, doses between 0.5 to $2 \mathrm{~g} / \mathrm{kg}$ caused DNA damage on brain tissue [115].

\section{Future Perspectives}

Aside from the widely recognized properties of Cecropia as antihypertensive and antidiabetic agents, other exciting effects highlight the industrial and pharmacological potential of the plants in this genus, making it worth encouraging their further development.

For instance, $C$. pachystachya and C. obtusa have been shown as promising candidates for dermo-cosmetic formulations to prevent skin aging or for photochemoprotection $[66,67]$. Special interest may be given to flavonoid-rich $C$. pachystachya extracts to treat and manage skin damage, due to their capacity to produce angiogenesis, epithelialization, and collagen deposition [69].

Other promising applications include the further study of Cglycosyl flavonoid enriched fraction of C. glaziovii-loaded nanospheres and standardized hydroethanolic C. glaziovii-loaded PLGA microparticles as drug delivery systems to treat labial herpes and hypertension [117-119]. In these investigations, the developed particle preparations were proposed to be capable of overcoming the bioavailability, permeability, and solubility issues associated with flavonoids $[118,119]$. Additionally, a magnetic emulsion nanoparticle of maghemite dispersed in an aqueous extract of C. obtusifolia leaves provided long-term biocompatibility and chemical stability to the extract [120]. Further research in the field of nanocomposite particles as drug delivery systems would be a fruitful and interesting area to explore.

There is also evidence that $C$. pachystachya may be useful in the prevention of bipolar disorder by reducing the episode relapse and the oxidative damage observed in its manic phase [57]; that triterpenes obtained from C. lyratiloba have the potential to develop multidrug resistance anticancer agents [104,106]; and that the triterpenes from $C$. telenitida may become novel immunomodulatory/anti-inflammatory drugs [7].

Finally, the capacity of C-glycosyl flavonoids, rutin, and chlorogenic acid (from $C$. pachystachya) to act as quorum sensing inhibitors of C. violaceum and E. coli [108] proposes a novel biotechnological application yet to be exploited.

\section{Conclusions}

Synonymized entities or identified morphotypes in the genus Cecropia may represent new species. Those unresolved species complexes may lead to inaccurate taxon selection and imprecise assessments of biodiversity, conservation, biogeography, and speciation processes $[121,122]$. Additionally, a bad taxonomic circumscription or an inaccurate identification could also lead to misinterpretations of the results in pharmaceutical research of natural products [123-126]. Therefore, additional taxonomic, molecular, morphological, chemical studies, extensive additional fieldwork, nomenclatural studies, and a thorough examination of specimens must be carried out to confirm their identities.

There is evidence that for the genus Cecropia specific secondary metabolites differ both quantitatively and qualitatively among closely related species, within a single species, and among members of a population. The phytochemical content of Cecropia leaves might be highly influenced by various factors such as genotypic differences, genetic aspects, climatic conditions, and harvesting methods. These factors should be further investigated to address this issue.

The therapeutic properties of the plants in this genus have generally been attributed to its chemical composition consisting mainly of terpenoids, steroids [5], chlorogenic- and caffeic acid [96], proanthocyanidins, flavonoids [3], and other phenolic compounds [15]. For instance, chlorogenic acid and isoorientin have been well identified as key constituents responsible for the hypoglycemic effect of $C$. obtusifolia and $C$. peltata. Similarly, the presence of flavonoids, catechins, proanthocyanidins, terpenic, and steroidal compounds have been associated with the antihypertensive and anti-inflammatory activities of C. glaziovii and C. pachystachya.

In several studies, synergism has been proposed as the mechanism of action for Cecropia extracts $[58,90]$. Thus, a mixture of phytoconstituents may be responsible for the complex pharmacological effects of these extracts, and it may be the reason why it has been difficult to correlate individual compounds with specific biological activities. 
Caution must be taken when comparing results from extracts obtained from different Cecropia species, since chemical composition may vary among species and geographical location.

Variation in the chemical composition of extracts may depend on the method of extraction but also on the species and the collection site. Although some species of this genus have enough scientific support and preliminary analytical methods to be recommended as phytomedicines, other species still require additional studies to improve the methodology to assure its quality, safety, and efficacy.

While the medicinal use of plants of this genus has been officially documented in National Pharmacopoeias and Formularies of several Latin American countries, it is important to understand that these are complex mixtures requiring a thorough understanding of their chemical composition and their correlation with their biological activities to be recognized as phytomedicines.

\section{Supporting Information}

Table 1S provides the key morphological characteristics of the genus Cecropia. Additionally, Tables 2S, 3S, and 4S show detailed content of chemicals present in the 10 species of Cecropia, selected for this review. Finally, Table $5 \mathrm{~S}$ summarizes the most relevant pharmacological activities of this genus.

\section{Contributors' Statement}

Conception of the work: C. Caballero-George; design: A. RiveraMondragon, O.O. Ortiz, M.P. Gupta, C. Caballero-George; data acquisition: A. Rivera-Mondragon, O.O. Ortiz, M.P. Gupta, C. Caballero-George; data interpretation: A. Rivera-Mondragon, O. O. Ortiz, M. P. Gupta, C. Caballero-George; drafting the manuscript: A. Rivera-Mondragon, O. O. Ortiz, M. P. Gupta, C. CaballeroGeorge; critical revision of the manuscript: C. Caballero-George.

\section{Acknowledgements}

The authors gratefully acknowledge financial support through grants FID14-116 from the National Secretariat for Science, Technology, and Innovation (SENACYT), and CC02-2020 from the Institute of Scientific Research and High Technology Services (INDICASAT AIP). Thanks are also due to the incentive program of the National Investigation System (SNI) of the Republic of Panama for supporting Dr. Caballero-George and Dr. Rivera-Mondragon.

\section{Conflict of Interest}

The authors declare that they have no conflict of interest.

\section{References}

[1] Berg C, Franco-Roselli P. Cecropia. Flora Neotrop 2005; 94: 1-230

[2] Franco-Rosselli P, Berg CC. Distributional patterns of Cecropia (Cecropiaceae): a panbiogeographic analysis. Caldasia 1997; 19: 285-296

[3] Luengas-Caicedo PE, Braga FC, Brandão GC, De Oliveira AB. Seasonal and intraspecific variation of flavonoids and proanthocyanidins in Cecropia glaziovi Sneth. leaves from native and cultivated specimens. Z Naturforsch C J Biosci 2007; 62: 701-709

[4] Costa GM, Schenkel EP, Reginatto FH. Chemical and pharmacological aspects of the genus Cecropia. Nat Prod Comun 2011; 6: 913-920
[5] Ospina Chávez ], Rincón Velanda J, Guerrero Pabón M. Perfil neurofarmacológico de la fracción butanólica de las hojas de Cecropia peltata L. Rev Colomb Ciencias Quím Farm 2013; 42: 244-259

[6] Hernández Carvajal JE, Luengas Caicedo PE. Estudio fitoquímico preliminar de Cecropia membranacea Trécul. y Cecropia metensis Cuatrec. Rev Cuba Plantas Med 2013; 18: 586-595

[7] Montoya Peláez GL, Sierra JA, Alzate F, Holzgrabe U, Ramirez-Pineda JR. Pentacyclic triterpenes from Cecropia telenitida with immunomodulatory activity on dendritic cells. Brazilian J Pharmacogn 2013; 23: 754-761

[8] Monro A. Neotropical Urticaceae. In: Millike W, Klitgård B, Baracat A, eds. Neotropikey-interactive key and information resources for flowering plants of the Neotropics. 2009. Accessed January 10, 2021 at: http://www.kew.org/science/tropamerica/neotropikey/families/ Urticaceae.htm

[9] Conn BJ, Hadiah JT, Webber BL. The status of Cecropia (Urticaceae) introductions in Malesia: addressing the confusion. Blumea J Plant Taxon Plant Geogr 2012; 57: 136-142

[10] Gutiérrez-Valencia J, Chomicki G, Renner SS. Recurrent breakdowns of mutualisms with ants in the neotropical ant-plant genus Cecropia (Urticaceae). Mol Phylogenet Evol 2017; 111: 196-205

[11] Treiber EL, Gaglioti AL, Romaniuc-Neto S, Madriñán S, Weiblen GD. Phylogeny of the Cecropieae (Urticaceae) and the evolution of an antplant mutualism. Syst Bot 2016; 41: 56-66

[12] Dejean A, Leroy C, Corbara B, Céréghino R, Roux O, Hérault B, Rossi V, Guerrero RJ, Delabie JHC, Orivel J, Boulay R. A temporary social parasite of tropical plant-ants improves the fitness of a myrmecophyte. Naturwissenschaften 2010; 97: 925-934

[13] Oliveira KN, Coley PD, Kursar TA, Kaminski LA, Moreira MZ, Campos RI. The effect of symbiotic ant colonies on plant growth: a test using an Azteca-Cecropia system. PLoS One 2015; 10: e0120351

[14] Caballero-George C, Vanderheyden P, Solis P, Pieters L, Shahat A, Gupta M, Vauquelin G, Vlietinck A. Biological screening of selected medicinal Panamanian plants by radioligand-binding techniques. Phytomedicine 2001; 8: 59-70

[15] Gazal M, Ortmann CF, Martins FA, Streck EL, Quevedo ], de Campos AM, Stefanello FM, Kaster MP, Ghisleni G, Reginatto FH, Lencina CL. Antidepressant-like effects of aqueous extract from Cecropia pachystachya leaves in a mouse model of chronic unpredictable stress. Brain Res Bull 2014; 108: 10-17

[16] Pacheco NR, Pinto NC, da Silva JM, Mendes RF, da Costa JC, Aragão DM, Castañon M, Scio E. Cecropia pachystachya: a species with expressive in vivo topical anti-inflammatory and in vitro antioxidant effects. Biomed Res Int 2014; 2014: 1-10

[17] Pio-Corrêa M. Diccionário das Plantas Úteis do Brasil e das Exóticas Cultivadas. Rio de Janeiro: Ministério da Agricultura, Instituto Brasileiro de Desenvolvimento Florestal; 1978

[18] Matos JF. Plantas Medicinais: Guia de Seleção e Emprego de Plantas Usadas em Fitoterapia no Nordeste do Brasil. 2. ed. Fortaleza: IOCE; 1989

[19] Gupta MP. Cecropia pachystachya Mart. I. In: Gupta MP. Plantas medicinales Iberoamericanas. Santafé de Bogotá, Colombia: Convenio Andrés Bello, CYTED; 1995: 407-408

[20] Souccar C, Cysneiros RM, Tanae MM, Torres LMB, Lima-Landman MTR, Lapa AJ. Inhibition of gastric acid secretion by a standardized aqueous extract of Cecropia glaziovii Sneth and underlying mechanism. Phytomedicine 2008; 15: 462-469

[21] Tanae MM, Lima-Landman MT, De Lima TC, Souccar C, Lapa A. Chemica standardization of the aqueous extract of Cecropia glaziovii Sneth endowed with antihypertensive, bronchodilator, antiacid secretion and antidepressant-like activities. Phytomedicine 2007; 14: 309-313

[22] Petenatti EM, Petenatti ME, del Vitto LA. Medicamentos herbarios en e Centro-Oeste argentino. "Ambay": control de calidad de la droga oficial y sus adulterantes. Acta Farm Bonaer 1998; 17: 197-212 
[23] [FHEUM] Farmacopea Herbolaria de los Estados Unidos Mexicanos-Secretaría de Salud. Cecropia obtusifolia Bertol. 1840 1. ed. Spanish. Mexico: Comisión Permanente de la Farmacopea de los Estados Unidos Mexicanos; 2001

[24] Consolini AE, Migliori GN. Cardiovascular effects of the South American medicinal plant Cecropia pachystachya (ambay) on rats. J Ethnopharmacol 2005; 96: 417-422

[25] Berg C. Cecropiaceae a new family of the Urticales. Taxon 1978; 27: 3944

[26] Engler H. Ulmaceae, Moraceae, Urticaceae. In: Engler H, Prantl K, ed. Die natürlichen Pflanzenfamilien nebst ihren Gattungen und wichtigeren Arten, insbesondere den Nutzflanzen, unter Mitwirkung zahlreicher hervorragender Fachgelehrten begründet. Leipzig: Wilhelm Engelmann; 1889: $59-118$

[27] Corner EJH. The classification of Moraceae. Gard Bull Singapore 1962; 19: $187-252$

[28] Chew WL. A revision of the genus Poikilospermum. Gard Bull Singapore 1963; 20: 1-104

[29] Cronquist A. An Integrated System of Classification of Flowering Plants. New York: Columbia Univ Press 1981; 1262

[30] Sytsma KJ, Morawetz ], Pires JC, Nepokroeff M, Conti E, Zjhra M, Hall JC, Chase MW. Urticalean rosids: circumscription, rosid ancestry, and phylogenetics based on rbcL, trnL-F, and ndhF sequences. Am J Bot 2002; 89: 1531-1546

[31] Monro AK. The revision of species-rich genera: a phylogenetic framework for the strategic revision of Pilea (Urticaceae) based on cpDNA, nrDNA, and morphology. Am J Bot 2006; 93: 426-441

[32] Datwyler SL, Weiblen GD. On the origin of the fig: phylogenetic relationships of Moraceae from ndhF sequences. Am J Bot 2004; 91: 767-777

[33] Zerega NJC, Clement WL, Datwyler SL, Weiblen GD. Biogeography and divergence times in the mulberry family (Moraceae). Mol Phylogenet Evol 2005; 37: 402-416

[34] Hadiah JT, Conn BJ, Quinn C]. Infra-familial phylogeny of Urticaceae, using chloroplast sequence data. Aust Syst Bot 2015; 21: 375-385

[35] Clement WL, Weiblen GD. Morphological evolution in the mulberry family (Moraceae). Syst Bot 2009; 34: 530-552

[36] Wu ZY, Monro AK, Milne RI, Wang H, Yi TS, Liu J, Li DZ. Molecular phylogeny of the nettle family (Urticaceae) inferred from multiple loci of three genomes and extensive generic sampling. Mol Phylogenet Evol 2013; 69: 814-827

[37] Berg C, Akkermans R, van Heusden E. Cecropiaceae: Coussapoa and Pourouma, with an introduction to the family. Flora Neotrop 1990; 51 : $1-208$

[38] Snethlage E. Neue Arten der Gattung Cecropia nebst Beiträgen zu ihrer Synonymik. Notizbl Königl Bot Gart Berlin 1923; 8: 375-369. Accessed December 15, 2020 at: http://www.jstor.org/stable/25118139

[39] Duminil ], Kenfack D, Viscosi V, Grumiau L, Hardy OJ. Molecular phylogenetics and evolution testing species delimitation in sympatric species complexes: the case of an African tropical tree, Carapa spp. (Meliaceae). Mol Phylogenet Evol 2012; 62: 275-285

[40] Pinheiro F, Dantas-Queiroz MV, Palma-Silva C. Critical reviews in plant sciences plant species complexes as models to understand speciation and evolution: a review of South American studies. CRC Crit Rev Plant Sci 2018; 37: 54-80

[41] Ortiz OO, Rivera-Mondragón A, Pieters L, Foubert K, CaballeroGeorge C. Cecropia telenitida Cuatrec. (Urticaceae: Cecropieae): phytochemical diversity, chemophenetic implications, and new records from Central America. Biochem Syst Ecol 2019; 86: 103935

[42] Santos JDO, Zchonski FL, Pilati L, Gaglioti AL, Romaniuc-Neto S, DaSilva PR. Morphological and DNA analyses suggest the reinstatement of four synonymized Cecropia species. Tree Genet Genomes 2020; 16: 51
[43] Arend DP, dos Santos TC, Sonaglio D, dos Santos ALG, Reginatto FH, de Campos AM. Experimental design as a tool to evaluate chlorogenic and caffeic acids extracted from Cecropia glaziovii Sneth. J Pharm Biomed Anal 2011; 54: 58-68

[44] Rivera-Mondragón A, Broeckx G, Bijttebier S, Naessens T, Fransen E, Kiekens F, Caballero-George C, Vander Heyden Y, Apers S, Pieters L, Foubert K. Ultrasound-assisted extraction optimization and validation of an HPLC-DAD method for the quantification of polyphenols in leaf extracts of Cecropia species. Sci Rep 2019; 9: 2028

[45] Schmidt MEP, Pires FB, Bressan LP, da Silva FV, Lameira O, da Rosa MB. Some triterpenic compounds in extracts of Cecropia and Bauhinia species for different sampling years. Rev Bras Farmacogn 2018; 28: 21-26

[46] Guerrero El, Morán-Pinzón JA, Gabriel L, Olmedo D, López-Pérez JL, San Felicino A, Gupta MP. Vasoactive effects of different fractions from two Panamanians plants used in Amerindian traditional medicine. J Ethnopharmacol 2010; 131: 497-501

[47] Mosquera C, Panay AJ, Montoya G. Pentacyclic triterpenes from Cecropia telenitida can function as inhibitors of $11 \beta$-hydroxysteroid dehydrogenase type 1. Molecules 2018; 23: 1444

[48] Montoya G, Gutiérrez G, D’Vries R, Ellena J, Panay AJ. Spergulagenic acid A: isolation and single-crystal structure elucidation. J Mol Struct 2018; 1173: 937-941

[49] da Silva Mathias M, Rodrigues de Oliveira R. Differentiation of the phenolic chemical profiles of Cecropia pachystachya and Cecropia hololeuca. Phytochem Anal 2018; 24: 1-10

[50] Rivera-Mondragón A, Ortiz O, Bijttebier S, Vlietinck A, Apers S, Pieters L, Caballero-George $C$. Selection of chemical markers for the quality control of medicinal plants of the genus Cecropia. Pharm Biol 2017; 55: 1500-1512

[51] Ortmann CF, Abelaira HM, Réus GZ, Ignácio ZM, Chaves VC, dos Santos TC, de Carvalho P, Carlessi AS, Bruchchen L, Danielski LG, Cardoso SG, de Campos AM, Petronilho F, Rebelo J, dos Santos Morais MO, Vuolo F, DalPizzol F, Streck EL, Quevedo J, Reginatto FH. LC/QTOF profile and preliminary stability studies of an enriched flavonoid fraction of Cecropia pachystachya Trécul leaves with potential antidepressant-like activity. Biomed Chromatogr 2017; 31: e3982

[52] Costa GM, Ortmann CF, Schenkel EP, Reginatto FH. An HPLC-DAD method to quantification of main phenolic compounds from leaves of Cecropia species. J Braz Chem Soc 2011; 22: 1096-1102

[53] Pereira EDM, da Silva J, Carvalho PS, Grivicich I, Picada JN, Salgado Júnior IB, Vasques GJ, Pereira MAS, Reginatto FH, Ferraz ABF. In vivo and in vitro toxicological evaluations of aqueous extract from Cecropia pachystachya leaves. J Toxicol Environ Health A 2020; 83: 659-671

[54] Rivera-Mondragón A, Bijttebier S, Tuenter E, Custers D, Ortiz OO, Pieters L, Caballero-George C, Apers S, Foubert K. Phytochemical characterization and comparative studies of four Cecropia species collected in Panama using multivariate data analysis. Sci Rep 2019; 9: 1763

[55] Costa GM, Ortmann CF, Schenkel EP, Reginatto FH. Seasonal variations in the amount of isoorientin and isovitexin in Cecropia glaziovii Sneth. leaves over a two-year period. Rev Colomb Cienc Quím Farm 2014; 43: $162-172$

[56] Cruz EDM, da Silva ER, Maquiaveli CDC, Alves ESS, Lucon JF, dos Reis MBG, de Toledo CEM, Cruz FG, Vannier-Santos MA. Leishmanicidal activity of Cecropia pachystachya flavonoids: arginase inhibition and altered mitochondrial DNA arrangement. Phytochemistry 2013; 89: 71-77

[57] Gazal M, Kaufmann FN, Acosta BA, Oliveira PS, Valente MR, Ortmann CF, Sturbelle R, Lencina CL, Stefanello FM, Kaster MP, Reginatto FH, Ghisleni G. Preventive effect of Cecropia pachystachya against ketamineinduced manic behavior and oxidative stress in rats. Neurochem Res 2015; 40: 1421-1430

[58] Lacaille-Dubois MA, Franck U, Wagner $\mathrm{H}$. Search for potential angiotensin converting enzyme (ACE)-inhibitors from plants. Phytomedicine 2001; 8: 47-52 
[59] Andrade-Cetto A, Heinrich M. Mexican plants with hypoglycaemic effect used in the treatment of diabetes. J Ethnopharmacol 2005; 99: 325-348

[60] Schinella G, Aquila S, Dade M, Giner R, Recio MC, Spegazzini E, de Buschiazzo P, Tournier H, Ríos JL. Anti-inflammatory and apoptotic activities of pomolic acid isolated from Cecropia pachystachya. Planta Med 2008; 74: 215-220

[61] Rivera-Mondragón A, Tuenter E, Bijttebier S, Cos P, Apers S, CaballeroGeorge C, Foubert K, Pieters L. Two new antiplasmodial flavonolignans from the leaves of Cecropia obtusifolia. Phytochem Lett 2019; 31: 118120

[62] Feltrin C, Farias IV, Sandjo LP, Reginatto FH, Simões CMO. Effects of standardized medicinal plant extracts on drug metabolism mediated by CYP3A4 and CYP2D6 enzymes. Chem Res Toxicol 2020; 33: 2408-2419

[63] Yan Y, Hao Y, Hu S, Chen X, Bai X. Hollow fibre cell fishing with high performance liquid chromatography for screening bioactive anthraquinones from traditional Chinese medicines. J Chromatogr A 2013; 1322: $8-17$

[64] Machado E, Cardoso O, Lima NM, Carvalho PE, Barbosa AD, Sobrinho GF, Duarte JF, Coelho LR, Soares PPC, Orneles AG, Santos ACB, Santos KB, Castro SBR, de Oliveira MAL, Carli AP, Cesar C, Souza Alves Souza CC. Cecropia hololeuca: a new source of compounds with potential anti-inflammatory action. Nat Prod Res 2019; 11: 1-6

[65] Aragão DMO, Guarize L, Lanini J, da Costa J, Garcia RMG, Scio E. Hypoglycemic effects of Cecropia pachystachya in normal and alloxan-induced diabetic rats. J Ethnopharmacol 2010; 128: 629-633

[66] Fernandes MF, Conegundes JLM, Pinto NCC, de Oliveira LG, de Aguiar JAK, Souza-Fagundes EM, Scio E. Cecropia pachystachya leaves present potential to be used as new ingredient for antiaging dermocosmetics. Evid Based Complement Altern Med 2019; 2019: 8263934

[67] Alves GAD, Oliveira de Souza R, Ghislain Rogez HL, Masaki H, Fonseca MJV. Cecropia obtusa extract and chlorogenic acid exhibit anti aging effect in human fibroblasts and keratinocytes cells exposed to UV radiation. PLoS One 2019; 14: e0216501

[68] Alves GAD, de Souza RO, Rogez H, Masaki H, Fonseca MJV. Cecropia obtusa, an Amazonian ethanolic extract, exhibits photochemoprotective effect in vitro and balances the redox cellular state in response to UV radiation. Ind Crops Prod 2016; 94: 893-902

[69] Duque APN, Pinto NCC, Mendes RF, da Silva JM, Aragão DMO, Castañon MCMN, Scio E. In vivo wound healing activity of gels containing Cecropia pachystachya leaves. J Pharm Pharmacol 2016; 68: 128-138

[70] Nayak BS. Cecropia peltata L (Cecropiaceae) has wound-healing potential: a preclinical study in a Sprague Dawley rat model. Int J Low Extrem Wounds 2006; 5: 20-26

[71] Arend DP, dos Santos TC, Cazarolli LH, Hort MA, Sonaglio D, dos Santos ALG, Ribeiro-do-Valle RM, Silva FRMB, de Campos AM. In vivo potential hypoglycemic and in vitro vasorelaxant effects of Cecropia glaziovii standardized extracts. Rev Bras Farmacogn 2015; 25: 473-484

[72] Mellado V, Lozoya M. Effect of the aqueous extract of Cecropia obtusifolia on the blood sugar of normal and pancreatectomized dogs. Int J Crude Drug Res 1984; 22: 11-16

[73] Andrade-Cetto A, Wiedenfeld H. Hypoglycemic effect of Cecropia obtusifolia on streptozotocin diabetic rats. J Ethnopharmacol 2001; 78: 145149

[74] Pérez RM, Ocegueda A, Muñoz JL, Avila JG, Morrow W. A study of the hypoglucemic plants effect of some mexican plants. J Ethnopharmacol 1984; 12: 253-262

[75] Román-Ramos R, Flores-Sáenz JL, Partida-Hernández G, Lara-Lemus A, Alarcón-Aguilar FJ. Experimental study of the hypoglycemic effect of some antidiabetic plants. Arch Invest Med (Mex) 1991; 22: 87-93

[76] Verspohl Ej. Recommended testing in diabetes research. Planta Med 2002; 68: 581-590
[77] Nicasio P, Aguilar-Santamaría L, Aranda E, Ortiz S, González M. Hypoglycemic effect and chlorogenic acid content in two Cecropia species. Phyther Res 2005; 19: 661-664

[78] Andrade-Cetto A, Becerra-Jiménez J, Cárdenas-Vázquez R. Alfa-glucosidase-inhibiting activity of some Mexican plants used in the treatment of type 2 diabetes. J Ethnopharmacol 2008; 116: 27-32

[79] Alonso-Castro AJ, Miranda-Torres AC, González-Chávez MM, SalazarOlivo LA. Cecropia obtusifolia Bertol and its active compound, chlorogenic acid, stimulate 2-NBDglucose uptake in both insulin-sensitive and insulin-resistant 3T3 adipocytes. J Ethnopharmacol 2008; 120: 458-464

[80] Andrade-Cetto A, Vázquez RC. Gluconeogenesis inhibition and phytochemical composition of two Cecropia species. J Ethnopharmacol 2010; 130: 93-97

[81] Revilla-Monsalve MC, Andrade-Cetto A, Palomino-Garibay MA, Wiedenfeld $\mathrm{H}$, Islas-Andrade S. Hypoglycemic effect of Cecropia obtusifolia Bertol aqueous extracts on type 2 diabetic patients. J Ethnopharmacol 2007; 111: 636-640

[82] Herrera-Arellano A, Aguilar-Santamaría L, García-Hernández B, NicasioTorres P, Tortoriello J. Clinical trial of Cecropia obtusifolia and Marrubium vulgare leaf extracts on blood glucose and serum lipids in type 2 diabetics. Phytomedicine 2004; 11: 561-566

[83] Cadena-Zamudio JD, Nicasio-Torres MP, Guerrero-Analco JA, IbarraLaclette E. Ethnopharmacological studies of Cecropia obtusifolia (Urticaceae) and its importance in the treatment of type 2 diabetes mellitus: a mini-review. Acta Bot Mex 2019; 126: e1361

[84] Andrade-Cetto A, Cárdenas R, Ramírez-Reyes B. Hypoglycemic effect of Cecropia peltata L. on N5-STZ type 2 diabetic rats. Pharmacologyonline 2007; 3: 203-210

[85] Lapa A], Lima-Landman MTR, Cysneiros RM, Borges ACR, Souccar C, Barreta IP, Lima TCM. The Brazilian Folk Medicine Program to Validate Medicinal Plants-A Topic in new Antihypertensive Drug Research. In: Hostettmann K, Gupta MP, Marston A, eds. Chemistry, Biological and Pharmacologycal Properties of Medicinal Plants from the Americas. Proceeding of the IOCD/CYTED Symposium, Panama City, Panama, 23-26 February 1997. London: Routledge; 1999: 185-196

[86] Lima-Landman MT, Borges AC, Cysneiros RM, de Lima TCM, Souccar C, Lapa AJ. Antihypertensive effect of a standardized aqueous extract of Cecropia glaziovii Sneth in rats: an in vivo approach to the hypotensive mechanism. Phytomedicine 2007; 14: 314-320

[87] Ninahuaman MFML, Souccar C, Lapa J, Lima-Landman MTR. ACE activity during the hypotension produced by standardized aqueous extract of Cecropia glaziovii Sneth: a comparative study to captopril effects in rats. Phytomedicine 2007; 14: 321-327

[88] Salas I, Brenes JR, Morales OM. Antihypertensive effect of Cecropia obtusifolia (Moraceae) leaf extract on rats. Rev Biol Trop 1987; 35: 127-130

[89] Vidrio H, García-Márquez F, Reyes J, Soto RM. Hypotensive activity of Cecropia obtusifolia. J Pharm Sci 1982; 71: 475-476

[90] Ramos Almeida R, Montani Raimundo J, Rodrigues Oliveira R, Coelho Kaplan MA, Gattass CR, Sudo RT, Zapata-Sudo G. Activity of Cecropia lyratiloba extract on contractility of cardiac and smooth muscles in Wistar rats. Clin Exp Pharmacol Physiol 2006; 33: 109-113

[91] Oliveira RR, Moraes MCC, Castilho RO, Valente AP, Carauta JPP, Lopes D, Kaplan MAC. High-speed countercurrent chromatography as valuable tool to isolate C-glycosylflavones from Cecropia lyratiloba Miquel. Phytochem Anal 2003; 14: 96-99

[92] Consolini AE, Ragone MI, Migliori GN, Conforti P, Volonté MG. Cardiotonic and sedative effects of Cecropia pachystachya Mart. (ambay) on isolated rat hearts and conscious mice. J Ethnopharmacol 2006; 106: 90-96

[93] Maquiaveli CC, da Silva ER, Rosa LC, Francescato HDC, Lucon Júnior JF, Silva CGA, Casarini DE, Ronchi FA, Coimbra TM. Cecropia pachystachya extract attenuated the renal lesion in $5 / 6$ nephrectomized rats by reducing inflammation and renal arginase activity. J Ethnopharmacol 2014; 158: 49-57 
[94] do C Maquiaveli C, da Silva ER, Francescato HD, Costa RS, Silva CG, Casarini DE, Ronchi FA, Coimbra TM. Brazilian embauba (Cecropia pachystachya) extract reduces renal lesions in 5/6 nephrectomized rats. J Renin Angiotensin Aldosterone Syst 2014; 15: 430-439

[95] Bipat R, Toelsie JR, Magali I, Soekhoe R, Stender K, Wangsawirana A, Oedairadjsingh K, Pawirodihardjo J, Mans DRA. Beneficial effect of medicinal plants on the contractility of post-hypoxic isolated guinea pig atria-potential implications for the treatment of ischemic-reperfusion injury. Pharm Biol 2016; 54: 1483-1489

[96] Müller SD, Florentino D, Flach C, Amélia F, Gainski L, Michels M, De Souza Constantino L, Petronilho F, Reginatto FH. Anti-inflammatory and antioxidant activities of aqueous extract of Cecropia glaziovii leaves. J Ethnopharmacol 2016; 185: 255-262

[97] Hikawczuk V], Saad JR, Guardia T, Juarez AO, Giordano O. Anti-inflammatory activity of compounds isolated from Cecropia pachystachya. An Asoc Quím Argent 1998; 86: 167-170

[98] Aragão MDO, Lima IV, da Silva JM, Bellozi PM, da Costa JDC, Cardoso GM, de Souza-Fagundes EM, Scio E. Anti-Inflammatory, antinociceptive and cytotoxic effects of the methanol extract of Cecropia pachystachya Trécul. Phyther Res 2013; 27: 926-930

[99] Ospina Chavez JA. Fraccionamiento bioguiado anticonvulsivante del extracto etanólico de las hojas de Cecropia peltata (Yarumo). [Thesis]. Bogota: Programa de Ciencias Farmacéuticas, Departamento de Farmacia, Facultad de Ciencias, Universidad Nacional de Colombia; 2010

[100] Rocha FF, Lima-Landman MT, Souccar C, Tanae MM, De Lima T, Lapa AJ. Antidepressant-like effect of Cecropia glaziovii Sneth and its constituents-In vivo and in vitro characterization of the underlying mechanism. Phytomedicine 2007; 14: 396-402

[101] Ortmann CF, Réus GZ, Ignácio ZM, Abelaira HM, Titus SE, de Carvalho P, Arent CO, dos Santos MAB, Matias BI, Martins MM, de Campos AM, Petronilho F, Texeira LJ, Morais MOS, Streck EL, Quevedo J, Reginatto FH. Enriched flavonoid fraction from Cecropia pachystachya Trecul leaves exerts antidepressant-like behavior and protects brain against oxidative stress in rats subjected to chronic mild stress. Neurotox Res 2016; 29: 469-483

[102] Delarcina S, Lima-Landman MTR, Souccar C, Cysneiros RM, Tanae MM, Lapa AJ. Inhibition of histamine-induced bronchospasm in guinea pigs treated with Cecropia glaziovii Sneth and correlation with the in vitro activity in tracheal muscles. Phytomedicine 2007; 14: 328-332

[103] Rosa HH, Carvalho P, Ortmann CF, Schneider NFZ, Reginatto FH, Simões CMO, Silva IT. Cytotoxic effects of a triterpene-enriched fraction of Cecropia pachystachya on the human hormone-refractory prostate cancer PC3 cell line. Biomed Pharmacother 2020; 130: 110551

[104] Rocha GG, Simões M, Lúcio KA, Oliveira RR, Coelho Kaplan MA, Gattass CR. Natural triterpenoids from Cecropia lyratiloba are cytotoxic to both sensitive and multidrug resistant leukemia cell lines. Bioorg Med Chem 2007; 15: 7355-7360

[105] Rocha GG, Simões M, Oliveira RR, Coelho Kaplan MA, Gattass CR. $3 \beta$-acetyl tormentic acid induces apoptosis of resistant leukemia cells independently of P-gp/ABCB1 activity or expression. Invest New Drugs 2012; 30: 105-113

[106] Rocha GG, Simões M, Oliveira RR, Coelho Kaplan MA, Gattass CR. Effects of $3 \beta$-acethyl tormentic acid (3ATA) on ABCC proteins activity. Int J Mol Sci 2012; 13: 6757-6771

[107] Uchôa VT, de Paula RC, Krettli LG, Santana AEG, Krettli AU. Antimalarial activity of compounds and mixed fractions of Cecropia pachystachya. Drug Dev Res 2010; 71: 82-91

[108] Brango-Vanegas J, Costa GM, Ortmann CF, Schenkel EP, Reginatto FH, Ramos FA, Arévalo-Ferro C, Castellanos L. Glycosylflavonoids from Cecropia pachystachya Trécul are quorum sensing inhibitors. Phytomedicine 2014; 21: 670-675

[109] Rojas J], Ochoa VJ, Ocampo SA, Muñoz JF. Screening for antimicrobial activity of ten medicinal plants used in Colombian folkloric medicine: a possible alternative in the treatment of non-nosocomial infections. BMC Complement Altern Med 2006; 6: 2

[110] Petronilho F, Dal-Pizzol F, Costa GM, Kappel VD, de Oliveira SQ, Fortunato J, Cittadini-Zanette V, Moreira JCF, Simoes CMO, Dal-Pizzol F, Reginatto FH. Hepatoprotective effects and HSV-1 activity of the hydroethanolic extract of Cecropia glaziovii (embaúba-vermelha) against acyclovir-resistant strain. Pharm Biol 2012; 50: 911-918

[111] Randazzo-Moura P. The effect of aqueous extract of Cecropia glazioui Snethlage (Embauba) in the rat fetal development. Chin Med 2011; 2: 115-119

[112] Gerenutti M, Prestes AF, Silva MG, del Fiol FDS, Franco YO, Venancio PC, Groppo FC. The effect of Cecropia glazioui Snethlage on the physical and neurobehavioral development of rats. Pharmazie 2008; 63: 398-404

[113] Pérez-Guerrero C, Herrera MD, Ortiz R, Alvarez de Sotomayor M, Fernández MA. A pharmacological study of Cecropia obtusifolia Bertol aqueous extract. J Ethnopharmacol 2001; 76: 279-284

[114] Martínez-Toledo V, Tellez MGO, Sortibrán ANC, Andrade-Cetto A, Rodríguez-Arnaiz R. Genotoxicity testing of Cecropia obtusifolia extracts in two in vivo assays: the wing somatic mutation and recombination test of Drosophila and the human cytokinesis-block micronucleus test. J Ethnopharmacol 2008; 116: 58-63

[115] Mendonça ED, da Silva J, dos Santos MS, Carvalho P, Papke DKM, Ortmann CF, Picada JN, Reginatto FH, de Barros Falcão Ferraz A. Genotoxic, mutagenic and antigenotoxic effects of Cecropia pachystachya Trécul aqueous extract using in vivo and in vitro assays. J Ethnopharmacol 2016; 193: 214-220

[116] Bigliani MC, Grondona E, Zunino PM, Ponce AA. Effects of Cecropia pachystachya and Larrea divaricata aqueous extracts in mice. Hum Exp Toxicol 2010; 29: 601-606

[117] dos Santos TC, Rescignano N, Boff L, Reginatto FH, Simões CMO, de Campos AM, Mijangos CU. Manufacture and characterization of chitosan/PLGA nanoparticles nanocomposite buccal films. Carbohydr Polym 2017; 173: 638-644

[118] dos Santos TC, Rescignano N, Boff L, Reginatto FH, Simões CMO, de Campos AM, Mijangos C. In vitro antiherpes effect of C-glycosyl flavonoid enriched fraction of Cecropia glaziovii encapsulated in PLGA nanoparticles. Mater Sci Eng C 2017; 75: 1214-1220

[119] dos Santos TC, Battisti MA, Lobo KL, Caon T, Linder AE, Sonaglio D, de Campos AM. Vasorelaxant effect of standardized extract of Cecropia glaziovii Snethl encapsulated in PLGA microparticles: In vitro activity, formulation development and release studies. Mater Sci Eng C 2018; 92: 228-235

[120] Santos JG, Silveira LB, Fegueredo PHS, Araujo BF, Peternele WS, Rodriguez AFR, Vilela EC, Garg VK, Oliveira AC, Azevedo RB, Morais PC. New magnetic fluid developed with natural organic compounds biocompatible. J Nanosci Nanotechnol 2012; 12: 4757-4761

[121] Heath TA, Hedtke SM, Hillis DM. Taxon sampling and the accuracy of phylogenetic analyses. J Syst Evol 2008; 46: 239-257

[122] Pinheiro F, Dantas-Queiroz MV, Palma-Silva C. Critical reviews in plant sciences plant species complexes as models to understand speciation and evolution: a review of South American studies. CRC Crit Rev Plant Sci 2018; 37: 54-80

[123] Bennett BC, Balick MJ. Does the name really matter? The importance of botanical nomenclature and plant taxonomy in biomedical research. J Ethnopharmacol 2014; 152: 387-392

[124] Rivera D, Allkin R, Obón C, Alcaraz F, Verpoorte R, Heinrich M. What is in a name? The need for accurate scientific nomenclature for plants. J Ethnopharmacol 2014; 152: 393-402

[125] Bussmann RW. Taxonomy - An irreplaceable tool for validation of herbal medicine. In: Mukherjee PK. Evidence-based validation of herbal medicine. Kolkata: Elsevier, 2015: 87-118 
[126] Weckerle CS, de Boer HJ, Puri K, van Andel T, Bussmann RW, Leonti M. Recommended standards for conducting and reporting ethnopharmacological field studies. J Ethnopharmacol 2017; 210: 125-132

[127] Paniagua Zambrana NY, Bussmann RW, Hart RE, Moya Huanca AL, Ortiz Soria G, Ortiz Vaca M, Ortiz Álvarez D, Soria Morán J, Soria Morán M, Chávez S, Chávez Moreno B, Chávez Moreno G, Roca O, Siripi E. Traditional knowledge hiding in plain sight-twenty-first century ethnobotany of the Chácobo in Beni, Bolivia. J Ethnobiol Ethnomed 2017; 13: 57

[128] Ríos M, Borgtoft Pedersen H. Las plantas y el hombre. Memorias del Primer Simposio Ecuatoriano de Etnobotánica y Botánica Económica. Quito, Ecuador: Ediciones ABYA-YALA; 1994: 436

[129] Botsaris AS. Plants used traditionally to treat malaria in Brazil: the archives of Flora Medicinal. J Ethnobiol Ethnomed 2007; 3: 1-8

[130] Agra MF, De Freitas PF, Barbosa-Filho JM. Synopsis of the plants known as medicinal and poisonous in Northeast of Brazil. Brazilian J Pharmacogn 2007; 17: 114-140

[131] Pérez R, Condit R. Tree atlas of the Panama Canal watershed. Trees, Shrubs, and Palms of Panama Cecropia insignis Liebm. Accessed January 8, 2021 at: http://ctfs.si.edu/webatlas/findinfo.php?leng= english\&specid=1269

[132] Sosa Gómez R. Guarumo. In: El Poder Medicinal de las Plantas. Miami, Florida: Asociación Publicadora Interamericana; 1997: 246-247

[133] Sequeda-Castañeda LG, Célis C, Ortíz-Ardila AE. Phytochemical and therapeutic use of Cecropia mutisiana Mildbr. (Urticaceae) an endemic plant from Colombia. Pharmacologyonline 2015; 3: 146-148

[134] Vael L. Ethnobotanical study of the plant use in the natural landscape of two mestizo communities in the Ucayali region of the Peruvian Amazon. [Masterproef]. Bogota: Universiteit Gent; 2015

[135] Aarland RC, Peralta-Gómez S, Sanchéz CM, Parra-Bustamante F, VillaHernández JM, de León-Sánchez FD, Pérez-Flores LJ, Rivera-Cabrera F, Mendoza-Espinoza JA. A pharmacological and phytochemical study of medicinal plants used in Mexican folk medicine. Indian J Tradit Knowl 2015; 14: 550-557

[136] Fernandez-Flores A, Llamas Velasco M, Saeb Lima M. El tratamiento de las verrugas con guarumbo por los zapotecos. Actas Dermosifiliogr 2020; 111: 189-191

[137] Garcia D, Domingues M, Rodrigues E. Ethnopharmacological survey among migrants living in the southeast Atlantic forest of Diadema, São Paulo, Brazil. J Ethnobiol Ethnomed 2010; 6: 29

[138] Ferreira Rodrigues Sarquis RDS, Rodrigues Sarquis Í, Rodrigues Sarquis I, Fernandes CP, Araújo G, Borja R, Augusto M, Gonçalves Jardim M, Sánchez-Ortiz BL, Carvalho JCT. The use of medicinal plants in the riverside community of the Mazagão river in the brazilian amazon, Amapá, Brazil: ethnobotanical and ethnopharmacological studies. Evid Based Complement Alternat Med 2019; 2019: 6087509

[139] Bieski IGC, Rios Santos F, de Oliveira RM, Espinosa MM, Macedo M, Albuquerque UP, de Oliveira Martins DT. Ethnopharmacology of medicinal plants of the pantanal region (Mato Grosso, Brazil). Evid Based Complement Alternat Med 2012; 2012: 1-36

[140] Silva EM, Souza JNS, Rogez H, Rees JF, Larondelle Y. Antioxidant activities and polyphenolic contents of fifteen selected plant species from the Amazonian region. Food Chem 2007; 101: 1012-1018

[141] Lans CA. Ethnomedicines used in Trinidad and Tobago for urinary problems and diabetes mellitus. J Ethnobiol Ethnomed 2006; 2: 45

[142] Clement YN, Baksh-Comeau YS, Seaforth CE. An ethnobotanical survey of medicinal plants in Trinidad. J Ethnobiol Ethnomed 2015; 11: 67

[143] Lans C, Harper T, Georges K, Bridgewater E. Medicinal and ethnoveterinary remedies of hunters in Trinidad. BMC Complement Altern Med 2001; $1: 10$
[144] Lans C, Turner N, Brauer G, Lourenco G, Georges K. Ethnoveterinary medicines used for horses in Trinidad and in British Columbia, Canada. Ethnobiol Ethnomed 2006; 2: 31

[145] Coe FG, Anderson G]. Screening of medicinal plants used by the Garifuna of Eastern Nicaragua for bioactive compounds. J Ethnopharmacol 1996; 53: 29-50

[146] Asprey GF, Thornton P. Medicinal Plants of Jamaica, Parts 1-4. West Indian J 1955; 2: 233-254

[147] Caceres A, Lopez BR, Giron MA, Logemann H. Plants used in Guatemala for the treatment of dermatophytic infections. 1. Screening for antimycotic activity of 44 plant extracts. J Ethnopharmacol 1991; 31: 263276

[148] Lisandro Vásquez M. Cecropia. In: Plantas y frutas medicinales de Colombia y América. Bogotá: Editorial Climent; 1982: 134-135

[149] Bussmann RW, Paniagua Zambrana NYP, Romero C, Hart RE. Astonishing diversity-the medicinal plant markets of Bogotá, Colombia. J Ethnobiol Ethnomed 2018; 14: 43

[150] DeFilipps R, Maina S, Crepin J. Medicinal Plants of the Guianas (Guyana, Surinam, French Guiana). Washington (DC): National Museum of Natural History, Smithsonian Institution; 2004

[151] Beyra A, León MC, Iglesias E, Ferrándiz D, Herrera R, Volpato G Godínez D, Guimarais M, Álvarez R. Estudios etnobotánicos sobre plantas medicinales en la provincia de Camagüey (Cuba). An del Jardín Botánico Madrid 2004; 61: 185-204

[152] Volpato G, Godínez D, Beyra A, Barreto A. Uses of medicinal plants by Haitian immigrants and their descendants in the province of Camagüey, Cuba. J Ethnobiol Ethnomed 2009; 5: 16

[153] Triana Salcedo IL. Purificación y caracterización de compuestos activos en Cecropia telenitida. Cali: Facultad de Ciencias Farmacéuticas, Universidad ICESI; 2018

[154] Fortis-Barrera MDLÁ, Alarcón-Aguilar F], Becerril-García A, FloresSáenz JLE, Almanza-Pérez JC, García-Lorenzana M, Lazzarini-Lechuga RC, Román-Ramos R, Blancas-Flores G. Mechanism of the hypoglycemic activity and hepatoprotective effect of the aqueous extract of Cecropia obtusifolia Bertol. J Med Food 2020; 23: 783-792

[155] Andrade-Cetto A, Cárdenas-Vázquez R, Ramírez-Reyes B. Hypoglycemic effect of Cecropia peltata I. on N5-STZ type 2 diabetic rats. Pharmacologyonline 2007; 3: 203-210

[156] Luiz TC, Rialto LH, De Moura FR, Aguiar DH, Sugui MM, Bicudo RC, Sinhorin AP, Sinhorin VDG. Chemoprotective effect of leaf extracts of Cecropia distachya Huber (Urticaceae) in mice submitted to oxidative stress induced by cyclophosphamide. Fronteiras 2020; 9: 103-127

[157] Oliveira RR, Leitao GG, Moraes MCC, Kaplan MAC, Lopes D, Carauta JPP. Gradient elution for triterpene separation from Cecropia lyratiloba Miquel by HSCCC. J Liq Chromatogr Relat Technol 2005; 28: 19851992

[158] Machado EC, Yunes RA, Malheiros A, Gomez EC, Delle Monache F. Two new $11 \alpha, 12 \alpha$-epoxy-ursan-28,13 $\beta$-olides and other triterpenes from Cecropia catharinensis. Nat Prod Res 2008; 22: 1310-1316

[159] Souza IT, Pereira CKB, Sant'Ana AEG, Oliveira BH. Ultrasound extraction and quantification of tormentic acid by HPLC in Cecropia pachystachya Trec. Acta Hortic 2018; 1198: 111-114

[160] Pires FB, Dolwitsch CB, Dal Prá V, Faccin H, Monego DL, de Carvalho LM, Viana C, Lameira O, Lima FO, Bressan L, da Rosa MB. Qualitative and quantitative analysis of the phenolic content of Connarus var. Angustifolius, Cecropia obtusa, Cecropia palmata and Mansoa alliacea based on HPLC-DAD and UHPLC-ESI-MS/MS. Rev Bras Farmacogn 2017; $27: 426-433$ 